\title{
Pegylated Interferon- $\alpha$ Modulates Liver Concentrations of Activin-A and Its Related Proteins in Normal Wistar Rat
}

\author{
Bassem Refaat, ${ }^{1}$ Adel Galal El-Shemi, ${ }^{1,2}$ Ahmed Mohamed Ashshi, ${ }^{1}$ \\ Elaf Wael Mahamid, ${ }^{1}$ and Noha Mohammed Al-Qadi ${ }^{1}$ \\ ${ }^{1}$ Laboratory Medicine Department, Faculty of Applied Medical Sciences, Umm Al-Qura University, \\ P.O. Box 7607, Al Abdeyah, Makkah, Saudi Arabia \\ ${ }^{2}$ Department of Pharmacology, Faculty of Medicine, Assiut University, Assiut 6515, Egypt
}

Correspondence should be addressed to Bassem Refaat; bassem.refaat@yahoo.co.uk

Received 27 February 2015; Revised 30 May 2015; Accepted 3 June 2015

Academic Editor: Limin Chen

Copyright (C) 2015 Bassem Refaat et al. This is an open access article distributed under the Creative Commons Attribution License, which permits unrestricted use, distribution, and reproduction in any medium, provided the original work is properly cited.

\begin{abstract}
Aims. To measure the expression of activin $\beta$ A-subunit, activin IIA and IIB receptors, Smad4, Smad7, and follistatin in the liver and the liver and serum concentrations of mature activin-A and follistatin in normal rat following treatment with pegylated interferon$\alpha$ (Peg-INF- $\alpha$ ) and ribavirin (RBV). Materials and Methods. 40 male Wistar rats were divided equally into 4 groups: "control," "Peg-only" receiving 4 injections of Peg-INF- $\alpha$ ( $6 \mu \mathrm{g} / \mathrm{rat} / \mathrm{week})$, "RBV-only" receiving ribavirin ( $4 \mathrm{mg} / \mathrm{rat} / \mathrm{day})$ orally, and "Peg \& RBV" group receiving both drugs. The expression of candidate molecules in liver was measured by immunohistochemistry and quantitative PCR. The concentrations of mature proteins in serum and liver homogenate samples were measured using ELISA. Results. Peg-INF- $\alpha \pm$ RBV altered the expression of all candidate molecules in the liver at the gene and protein levels $(P<0.05)$ and decreased activin-A and increased follistatin in serum and liver homogenates compared with the other groups $(P<0.05)$. There were also significant correlations between serum and liver activin-A and follistatin. Conclusion. Peg-INF- $\alpha$ modulates the hepatic production of activin-A and follistatin, which can be detected in serum. Further studies are needed to explore the role of Peg-INF- $\alpha$ on the production of activins and follistatin by the liver and immune cells.
\end{abstract}

\section{Introduction}

Infection with hepatitis $\mathrm{C}$ virus (HCV) is a global health problem and it is a leading cause for the development of liver fibrosis, cirrhosis, and hepatocellular carcinoma [1]. Although new directly acting antiviral drugs (DAAs) have been developed for the treatment of chronic hepatitis $\mathrm{C}$ $(\mathrm{CHC})$, these drugs are expensive and therefore pegylated interferon- $\alpha$ - (Peg-INF- $\alpha$-) 2a or $2 \mathrm{~b}$ plus a daily weight-based dose of ribavirin could still be the standard of care especially for the treatment of naïve patients with compensated liver functions and/or for those living in developing countries and for whom access to the new drugs is not definite [27]. In this regard, a large proportion of $\mathrm{CHC}$ patients lack adequate insurance limits to cover their access to DAAs [4]. Even in wealthy countries, reimbursement of DAAs is only allowed for $\mathrm{CHC}$ patients who are interferon unable, with advanced liver disease and/or transplanted organs due to the budget-breaking price of these oral medicines $[5,6]$. Hence, one possible approach to overcome the high cost of the DAAs could be by identifying those patients who could respond to the conventional Peg-INF- $\alpha$ based therapy as a first line of treatment $[2,3,5]$.

The development of hepatic complications following infection with $\mathrm{HCV}$ is due to the promotion of adaptive immune response by activating Thelper (Th) 2 pathway $[8,9]$. IFN- $\alpha$ alters the immune response in patients with $\mathrm{CHC}$ from Th2 to a Th1 mediated pattern, which favours the eradication of the virus $[10,11]$. INF- $\alpha$ induces Th1 response through the modulation of several cytokines including IFN- $\gamma$, tumour necrosis factor- (TNF-) $\alpha$, interleukins (IL), and transforming growth factor- (TGF-) $\beta$ by the hepatocyte and immune cells [12-14].

Activins are members of the TGF- $\beta$ family and their biological activities are tightly regulated by their binding protein follistatin [15]. Similar to any extracellular protein 
signals, activins execute their actions by binding to cell membrane receptors, namely, activin type I and type II receptors. Activins can bind to their individual receptor type II (IIA and IIB) when expressed alone, but they fail to bind to type I receptor in the absence of the type II receptor [15]. However, both receptor types are necessary to generate a high-affinity complex with activins, as well as for signalling. The activated activin type I receptor propagates the signal through the phosphorylation of other proteins known as Smad proteins $[16,17]$.

There are three functional classes of Smads: the receptorregulated Smad (R-Smad), the comediator Smad (Co-Smad), and the inhibitory Smad (I-Smad). The R-Smads (Smad1, Smad2, Smad3, Smad5, and Smad8) are directly phosphorylated and activated by the type I receptor kinases and undergo homotrimerization and formation of heteromeric complexes with the Co-Smad, known as Smad4. The activated Smad4 then enters the nucleus and initiates transcription of specific genes by the association with other regulatory factors $[16,17]$. Smad6 and Smad7, both are known as I-Smads, negatively regulate TGF- $\beta$ signalling by competing with the R-Smads for receptor or Co-Smad interaction and by targeting the receptors for degradation $[16,17]$.

Activin-A and follistatin are expressed by the hepatocyte and have been described as major regulators of liver biology, liver regeneration, and liver pathology [18]. Additionally, they play an important role in the regulation of the immune system and the pathogenesis of inflammatory and fibrotic human diseases [19]. Activin-A and follistatin have been proposed as diagnostic/prognostic markers for a variety of liver diseases since pathological alterations in their serum concentrations, which correlated with the severity of the diseases, have been documented in several liver pathologies including viral hepatitis B and hepatitis C $[20,21]$.

We have previously reported that $\mathrm{CHC}$ and Peg-INF- $\alpha$ based therapy modulate the serum concentrations of activinA and follistatin and we have postulated that Peg-INF- $\alpha$ alters the serum concentrations of these proteins by regulating their production in the liver $[22,23]$. Hence, the present study was conducted to measure the effects of Peg-INF- $\alpha$ based therapy on the expression of activin $\beta$ A-subunit, activin type IIA and IIB receptors, Smad4, Smad7, and follistatin in liver tissue collected from normal Wistar rat since it is not ethically possible to inject healthy human subjects with unnecessary drugs. Furthermore, the effects of Peg-INF- $\alpha$ based therapy on the concentrations of the mature activin-A and follistatin proteins were measured in liver homogenates and serum samples collected from the animals.

\section{Materials and Methods}

2.1. Drugs. Pegylated interferon- $\alpha$-2a (Pegasys, HoffmannLa Roche, Nutley, NJ) was used. The ready to use syringe contains $180 \mu \mathrm{g} / 0.5 \mathrm{~mL}$. Ribavirin capsules (Viracure, 6th October Pharm, Egypt) were used and each capsule contains $400 \mathrm{mg}$ of ribavirin.

2.2. Study Design. All experimental protocols were approved by the Committee for the Care and Use of Laboratory
Animals at Umm Al-Qura University and were in accordance with the EU Directive 2010/63/EU for animal experiments.

A total of 40 male Wistar rats weighing 250-300 gm were used. All animals received humane care during the study protocol and during euthanasia. The animals were divided equally into 4 groups as follows: the first group included 10 rats and they served as "control" group, the second group consisted of those that only received Peg-INF- $\alpha$ "Peg-only" group, the third received ribavirin only "RBV-only" group, and the last group consisted of rats that received both PegINF- $\alpha$ and ribavirin "Peg \& RBV" group.

The study duration was 5 weeks. Peg-INF- $\alpha-2$ a was prepared by diluting the content of a full syringe $(0.5 \mathrm{~mL})$ in normal saline to prepare a final volume of $10 \mathrm{~mL}$ and the final concentration was $18 \mu \mathrm{g} / \mathrm{mL}$. Each rat in the "Peg-only" and "Peg \& RBV" groups received a weekly subcutaneous injection of $0.33 \mathrm{~mL}(6 \mu \mathrm{g} / \mathrm{rat})$. Each rat received a total of 4 injections. One capsule of ribavirin $(400 \mathrm{mg})$ was dissolved in $50 \mathrm{~mL}$ saline and each rat in the "Peg \& RBV" and "RBV-only" groups received $0.5 \mathrm{~mL}$ ( $4 \mathrm{mg}$ )/day orally using a feeding syringe for the whole length of the study similar to the highest dose of the drug recommended from human during CHC treatment $(12 \mathrm{mg} / \mathrm{kg}$ [1200 mg for body weight $\geq 75 \mathrm{~kg}$ ]) [24]. Following 4 injections, the rats were sacrificed in the fifth week on the same day the 5 th injection would have been given. Ribavirin was continued till the day before euthanasia.

2.3. Types of Samples. All rats were sacrificed on the same day under diethyl ether anaesthesia (Fisher Scientific UK Ltd., Loughborough, UK) a week after the last injection and $4 \mathrm{~mL}$ of blood was collected in plain tube immediately after cutting the vena cava. Blood samples were centrifuged for 20 minutes and the serum was stored in $-20^{\circ} \mathrm{C}$ for routine biochemistry and to measure serum concentrations of activin-A and follistatin.

Two specimens from the middle lobe of the liver ( $2 \mathrm{gm} / \mathrm{each})$ were obtained from each animal with one piece being immediately processed for protein extraction using $6 \mathrm{~mL}$ of RIPA lysis buffer containing protease inhibitors (Santa-Cruz Biotechnology Inc., Burlingame, CA) and electrical homogeniser. All samples were centrifuged at $14000 \mathrm{rpm}$ for 30 minutes and small aliquots $(0.5 \mathrm{~mL})$ of the resultant supernatant were placed in Eppendorf tubes and stored in $-20^{\circ} \mathrm{C}$ till processed to measure the levels of candidate proteins in liver using ELISA.

The other liver specimen was divided equally with one piece that was immediately fixed in $10 \%$ buffered formalin for $24 \mathrm{~h}$ at room temperature, dehydrated with a series of different ethanol concentrations, and embedded in paraffin for immunohistochemistry. The remaining portion was immersed in $5 \mathrm{~mL}$ of RNAlater (Ambion, Thermo Fisher Scientific, USA) and stored in $-80^{\circ} \mathrm{C}$ to preserve their RNA stability for quantitative RT-PCR.

2.4. Immunohistochemistry. Polyclonal goat IgG antibodies to detect activin $\beta$ A-subunit (C-18), activin type IIA (N-17) and IIB (N-16) receptors, Smad4 (C-20), Smad7 (P-20), and 
follistatin (K-19) were obtained from Santa-Cruz Biotechnology Inc. (Burlingame, CA).

An avidin-biotin horseradish peroxidase technique was used to localize the proteins of interest. Briefly, paraffin embedded sections of $5 \mu \mathrm{m}$ thickness were dewaxed in xylene, dehydrated in alcohol, and treated with $2 \%$ (vol/vol) hydrogen peroxide for 20 minutes in methanol to block endogenous peroxidase. All sections were pretreated in an 850 -watt domestic microwave oven in $0.01 \mathrm{M}$ citrate buffer for 3 minutes. The sections were incubated for 30 minutes with normal donkey serum. The sections were then incubated with the primary antibodies (the antibody concentration was $1: 100$ for all used antibodies) overnight at $4^{\circ} \mathrm{C}$.

The following day the sections were washed with $20 \mathrm{mM}$ PBS ( $\mathrm{pH} 7.3$ ) and then incubated with 1:200 biotinylated anti-goat secondary antibody for 30 minutes. After a further wash step, the sections were incubated with the avidin-biotin peroxidase complex ABC system (Santa-Cruz Biotechnology Inc., Burlingame, CA) for 30 minutes and then subsequently with 3,3'-diaminobenzidine (Santa-Cruz Biotechnology Inc., Burlingame, CA) for 10 minutes. Sections were washed in tap water, counter-stained with Gill's haematoxylin, dehydrated in a series of graded ethanol, cleared in xylene, and mounted in DPX (BDH/Merck, Leicestershire, UK). The negative control slides consisted of a section of the tissue block being studied, which was treated identically to all other slides, with the exception that the primary antibody was omitted to control for nonspecific binding of the detection system.

For evaluation and scoring of immunohistochemical staining, the sections were observed on a Labor Lux microscope (Leitz, Wetzlar, Germany), at a magnification of $\times 100$, $\times 200$, and $\times 400$. A positive reaction was characterized by the presence of brown staining. Each section was examined by two observers who were blinded to the source of tissue and the intensity of staining was assessed using " $H$ score" which was calculated using the following equation [25]: $H$ score $=$ $\Sigma P_{i}(i+1)$, where $i$ represents the intensity of staining $(0=$ negative; $1=$ weak; $2=$ moderate; and $3=$ strong) and $P_{i}$ is the percentage of cells $(0-100 \%)$ stained at each intensity. In the case of a wide disagreement between the two observers, the slides were reanalyzed by a third independent reviewer. The final result was obtained by averaging the individual observer results. Representative sections were photographed using an Olympus digital camera at $\times 100$ magnification.

2.5. Measurement of Extracted Protein Concentrations. The concentrations of the total proteins extracted from the liver specimens were measured using the BioSpec-nano (Shimadzu Corporation, Japan) at 280 OD. All protein samples were diluted using normal saline to make a final concentration of $500 \mu \mathrm{g} / \mathrm{mL}$ as previously described [26].

2.6. Enzyme Linked Immunosorbent Assay (ELISA). ELISA was used for quantitative measurement of serum and liver activin-A and follistatin (R\&D systems, Minneapolis, USA). All samples were processed in duplicate and according to the manufacturer's instructions. The optical density of the plates was measured within $10 \mathrm{~min}$ using a plate reader at
$450 \mathrm{~nm}$ and correction at $560 \mathrm{~nm}$ as recommended by the manufacturer.

As reported by the manufacturer, the lowest detection limit of activin-A by the used kit is $3.7 \mathrm{pg} / \mathrm{mL}$ and the upper limit is $1500 \mathrm{pg} / \mathrm{mL}$. The intra-assay and interassay precisions of the kit are $4.3 \%$ and $5.8 \%$, respectively. The kit cross reacts by $0.2 \%$ and $0.45 \%$ with inhibin-A and activin- $A B$, respectively. The detection range of the follistatin kit is 250$16000 \mathrm{pg} / \mathrm{mL}$ and the minimum detectable dose is $83 \mathrm{pg} / \mathrm{mL}$.

2.7. RNA Extraction and cDNA Synthesis. Total RNA was isolated from the stored liver specimens in RNAlater following homogenisation of the specimens and by using the Purelink RNA mini kit from Life Technologies (Thermo Fisher Scientific, CA, USA) and according to the manufacturer's instructions. RNA was treated with RNAse-free DNAse during the extraction protocol to avoid the collection of genomic DNA and the concentrations and quality of the extracted total RNA were measured using the BioSpec-nano (Shimadzu Corporation, Japan), and its quality and integrity were concluded through the A260/A280 ratio.

For cDNA synthesis, 200 ng of total RNA was transcribed to cDNA using a high capacity RNA-to-cDNA Reverse Transcription Kit from Applied Biosystems (Thermo Fisher Scientific, Warrington, UK), following the manufacturer's protocol.

2.8. Quantitative RT-PCR. Quantitative RT-PCR was performed using the $2^{-\Delta \Delta C t}$ method on the following 6 target rat genes: activin $\beta$ A-subunit (NM_017128.2), activin type IIA receptor (NM_031571.2), activin type IIB receptor (NM_031554.1), follistatin (NM_012561.1), Smad4 (NM_ 019275.2), and Smad7 (NM_030858.1). The results were normalised against the $\mathrm{Ct}$ values of $\beta$-actin (NM_031144.3) and expressed as fold-change compared with the normal control group. The nucleotides primer sequences of these 7 rat origin genes are summarized in Table 1.

PCR reactions were carried out by using power SYBR Green master mix from Applied Biosystems (Thermo Fisher Scientific, Warrington, UK) and a step one Real Time PCR system (Applied Biosystems, USA) in triplicate wells. Each well of the PCR plate contained $10 \mu \mathrm{L}$ SYBR Green, $7 \mu \mathrm{L}$ DNase/RNase-free water, $1 \mu \mathrm{L}$ of each primer $(5 \mathrm{pmol})$, and $1 \mu \mathrm{L}$ cDNA (25 ng). The amplification was performed under the following conditions: 40 cycles $\left(95^{\circ} \mathrm{C} 15 \mathrm{~s}\right.$ and $60^{\circ} \mathrm{C}$ $1 \mathrm{~min})$. Two negative controls were included, one with minusreverse transcription (minus-RT) control from the previous reverse transcription step and a minus-template PCR, which contained all the PCR components, but water was used as a template.

2.9. Statistical Analysis. Statistical analysis of the results was performed using SPSS version 16. Normality and homogeneity of data were assessed with the Kolmogorov and Smirnoff test and Levene test, respectively. One-way ANOVA followed by Tukey's post hoc test or Kruskal-Wallis followed by Dunn's post hoc test was used to compare between the different groups depending on the data homogeneity. Correlations 
TABLE 1: The sequences of PCR primers used for the detection of $\beta$-actin, activin $\beta$ A-subunit, activin type IIA and IIB receptors, Smad4, Smad7, and follistatin including the corresponding genes accession numbers.

\begin{tabular}{lll}
\hline & Forward & Reverse \\
\hline $\begin{array}{l}\beta \text {-actin } \\
\text { NCBI: NM_031144.3) }\end{array}$ & $5^{\prime}$ CGG TCA GGT CAT CAC TAT CG 3' & $5^{\prime}$ TTC CAT ACC CAG GAA GGA AG 3' \\
$\begin{array}{l}\beta \text { A-subunit } \\
\text { NCBI: NM_017128.2) }\end{array}$ & $5^{\prime}$ GCT TTG GCT GAG AGG ATT TCT G 3' & $5^{\prime}$ TGG ATT ATA GTG AGG AGT TCC 3' \\
$\begin{array}{l}\text { IIA receptor } \\
\text { NCBI: NM_031571.2) }\end{array}$ & $5^{\prime}$ AGG CTA ATG TGG TCT CTT GGA A 3' & $5^{\prime}$ CCA ATC CTC TAG CCA TGG TTT CT 3' \\
$\begin{array}{l}\text { INCBI: NM_031554.1) } \\
\text { Smad4 }\end{array}$ & $5^{\prime}$ GGA GTG CAT CTA CTA CAA CGC 3' & $5^{\prime}$ TCC AGG CCG CTC TGG TT 3' \\
$\begin{array}{l}\text { Smad7 } \\
\text { (NCBI: NM_030858.1) }\end{array}$ & $5^{\prime}$ GTG GCT GGT CGG AAA GGA TTT 3' \\
$\begin{array}{l}\text { Follistatin } \\
\text { (NCBI: NM_012561.1) }\end{array}$ & $5^{\prime}$ GGA GGT CAT GTT CGC TCC TT 3' & 5' TTT GGT CCT GAA CAT GCG GG 3' \\
\hline
\end{tabular}

were determined using Pearson's test. $P$ value $<0.05$ was considered significant.

\section{Results}

3.1. Results of Routine Biochemistry. There was no significant difference $(P>0.05)$ using one way ANOVA between the different study groups in body weight, liver weight, liver enzymes, metabolic profile, and renal function parameters (Table 2).

3.2. Immunohistochemistry. All molecules were detected in the liver sections of all groups and the immunostain was localised in the cell membrane and cytoplasm of hepatocyte surrounding hepatic vessels (Figures 1-3). Furthermore, Smad4 and Smad7 exhibited nuclear localisation in the stained hepatocytes.

The use of Peg-INF- $\alpha$-2a either alone (Figures 1(c) and $1(\mathrm{~d})$ ) or in combination with RBV (Figures 1(e) and 1(f)) significantly decreased the expression of activin $\beta \mathrm{A}$-subunit (Figures 1(c) and 1(e)) and significantly increased the expression of follistatin (Figures $1(\mathrm{~d})$ and $1(\mathrm{f})$ ) compared with "control" (Figures 1(a) and 1(b)) and "RBV-only" groups (Figures $1(\mathrm{~g})$ and $1(\mathrm{~h})$ ). Similar to activin, the expression of type IIA and IIB receptors (Figure 2) and Smad4 (Figures 3(c)-3(f)) was also significantly decreased in the "Peg-INFonly" group (Figures 2 and 3(c) and 3(d)) and "Peg-INF and RBV" group (Figures 2 and $3(\mathrm{e})$ and $3(\mathrm{f})$ ) compared with the other groups (Table 3 ).

Smad7 showed a similar pattern of expression to follistatin as it was significantly higher in the group injected with Peg-INF- $\alpha$-2a alone (Figure $3(\mathrm{~d})$ ) or in combination with RBV (Figure 3(f)) compared with control (Figure 3(a)) and RBV-only (Figure 3(h)) groups. There was no significant difference in the expression of the candidate molecules between "RBV-only" and "control" groups $(P>0.05)$.

3.3. Concentrations of Serum and Liver Activin-A and Follistatin. Administration of Peg-INF- $\alpha$-2a for 4 weeks significantly decreased the concentrations of activin-A and significantly increased the concentrations of follistatin at both serum and liver levels of the "Peg-only" and "Peg \& RBV" groups compared to "control" group. Furthermore, significant differences were detected between "Peg \& RBV" and "Peg-only" in serum, but not liver, concentrations of candidate proteins (Table 4).

There was no significant difference in the concentrations of candidate proteins in the "RBV-only" and "control" groups at the serum and liver levels. However, a significant difference was detected in "RBV-only" compared to "Peg-only" and "Peg \& RBV" groups in serum and liver concentrations of activin$\mathrm{A}$ and follistatin.

3.4. Correlations between Serum and Liver Activin-A and Follistatin. There was a significant positive correlation between serum and liver concentrations of activin-A $(r=0.727$, $\left.P=0.02 \times 10^{-3}\right)$ and follistatin $(r=0.540, P=0.01)$. Serum activin-A also correlated negatively and significantly with serum follistatin $(r=-0.625, P=0.001)$ and liver follistatin $(r=-0.674, P=0.001)$. Additionally, a significant negative correlation was seen between liver activin-A and serum follistatin $(r=-0.560, P=0.009)$. However, there was a nonsignificant correlation between liver activin-A and liver follistatin (Figure 4).

3.5. Quantitative RT-PCR. Gene expression study showed a significant decrease in the mRNA expression of activin $\beta A$ subunit (5-fold), type IIA (3.8-fold) and type IIB (5-fold) receptors, and Smad4 (7-fold) in the groups injected with Peg-INF- $\alpha$-2a (Figure 5). Furthermore, a significant increase was observed $(P<0.05)$ in the gene expression of follistatin (3-fold) and Smad7 (3-fold) in the "Peg-INF- $\alpha$ " and "PegINF- $\alpha$ and RBV" groups when compared with the "control" and "RBV" groups (Figure 5). Nevertheless, there was no significant difference in the expression of the genes of interest between "RBV" and "control" groups $(P>0.05)$.

\section{Discussion}

To the best of our knowledge, this is the first study to report the effect of Peg-INF- $\alpha$ and ribavirin on the expression of 


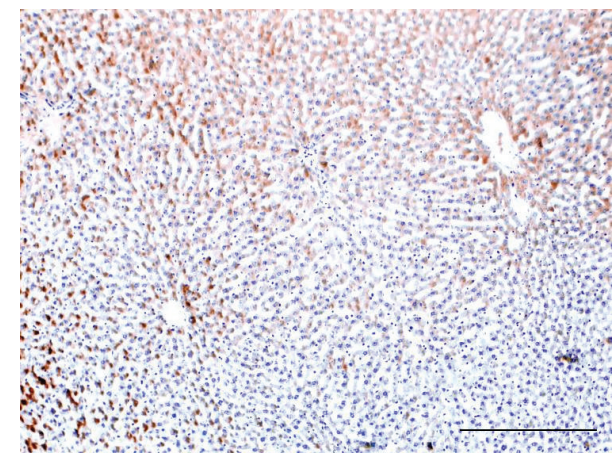

(a)

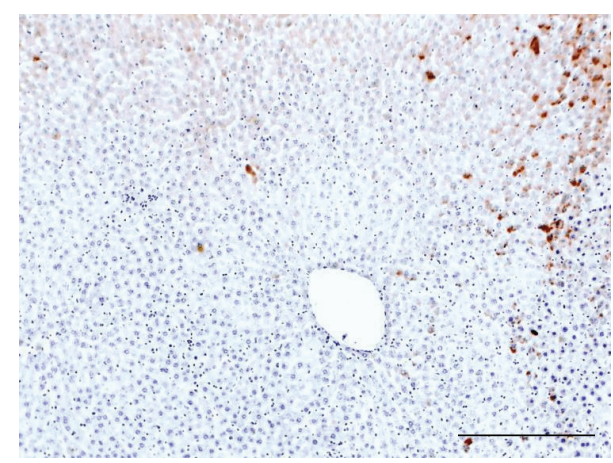

(c)

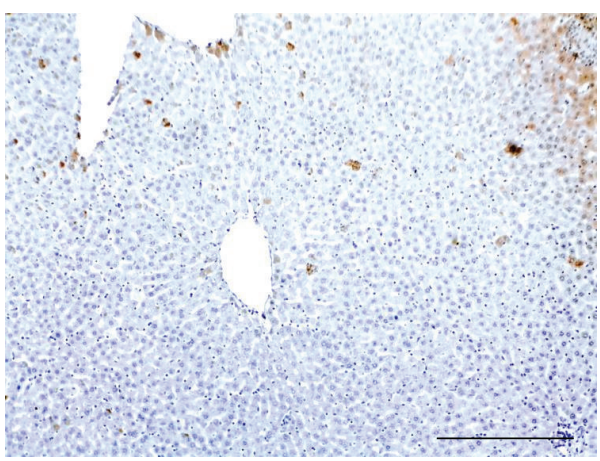

(e)

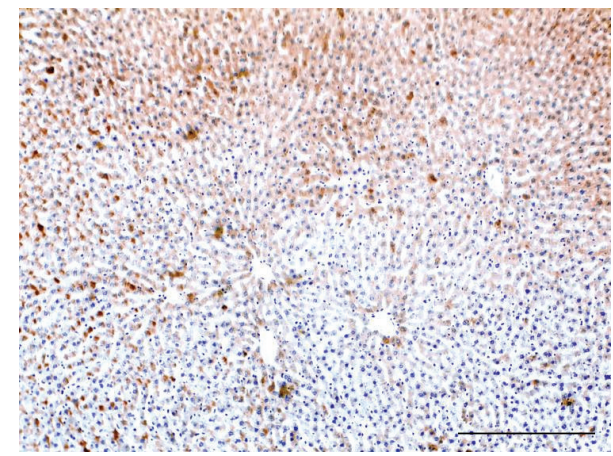

(g)

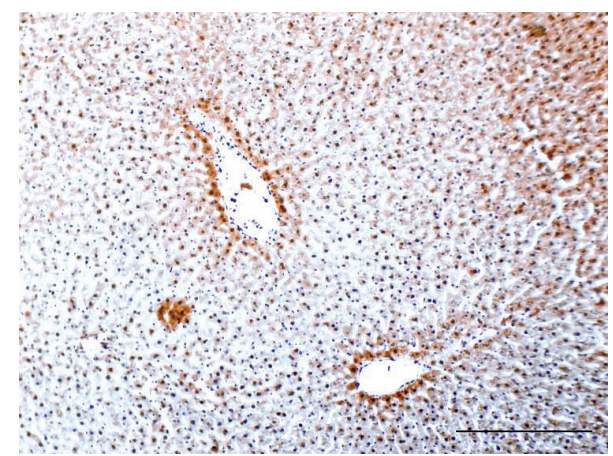

(b)

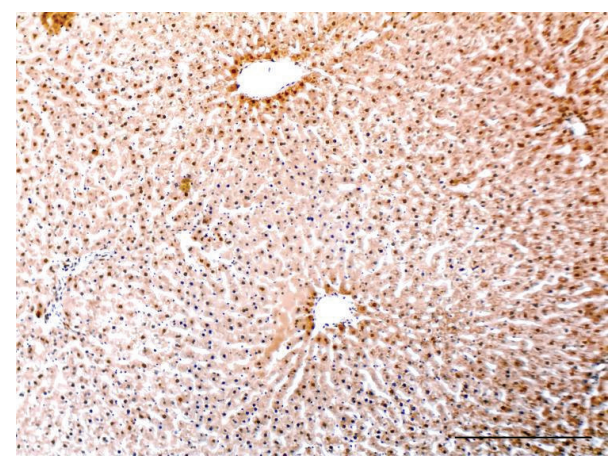

(d)

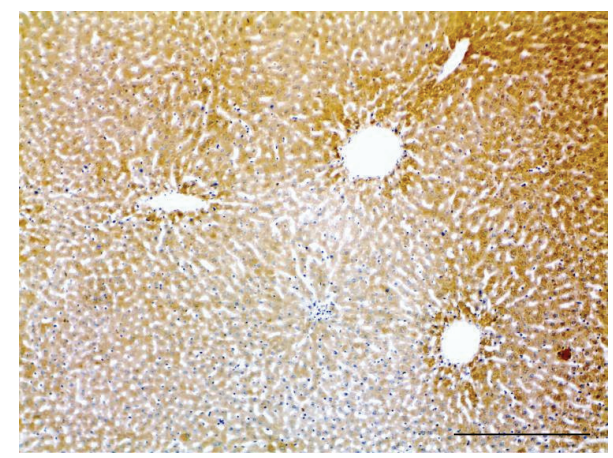

(f)

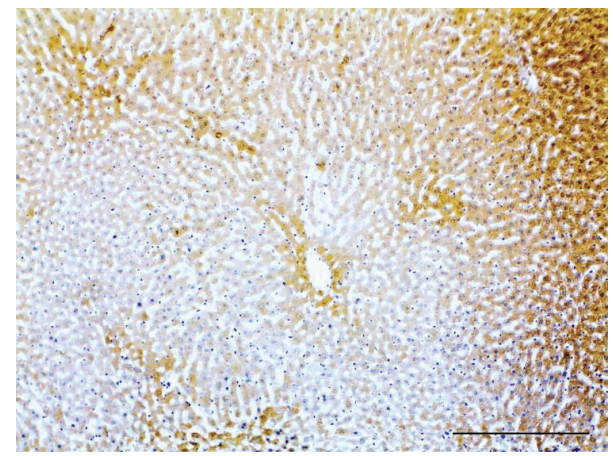

(h)

FIGURE 1: Immunohistochemistry localisation of activin $\beta$ A-subunit (left column) and follistatin (right column) in control (a and b), Peg-only (c and d), Peg \& RBV (e and f), and RBV-only (g and h) groups ( $\times 100$ magnification, scale bar $=15 \mu \mathrm{m})$. 


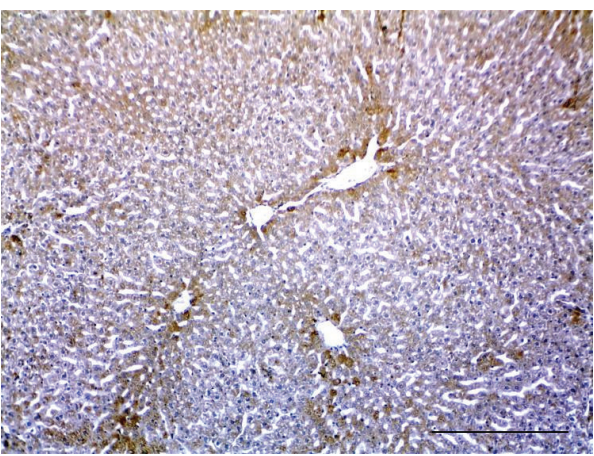

(a)

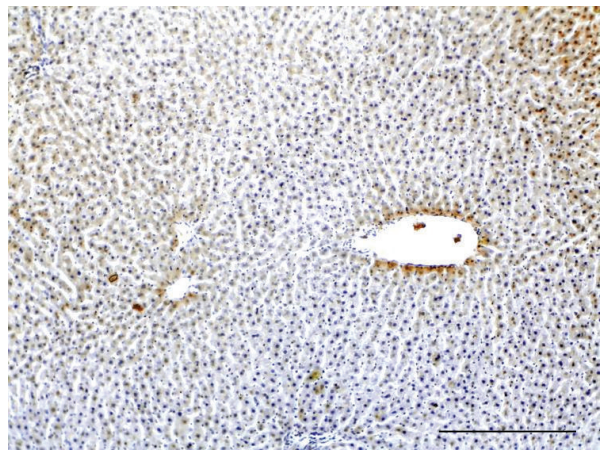

(c)

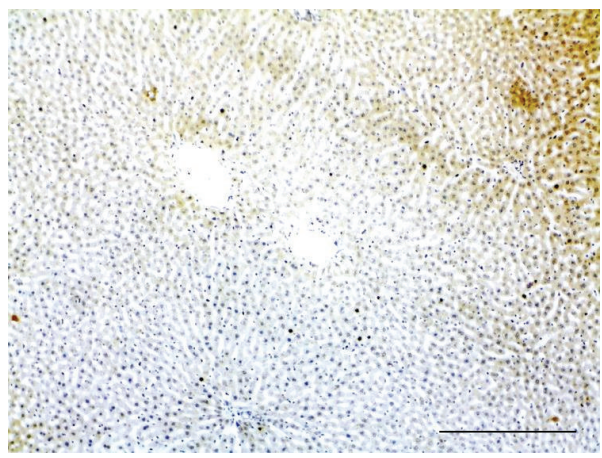

(e)

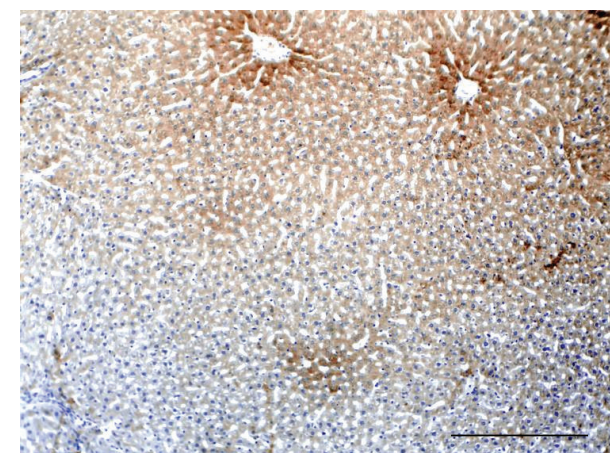

(g)

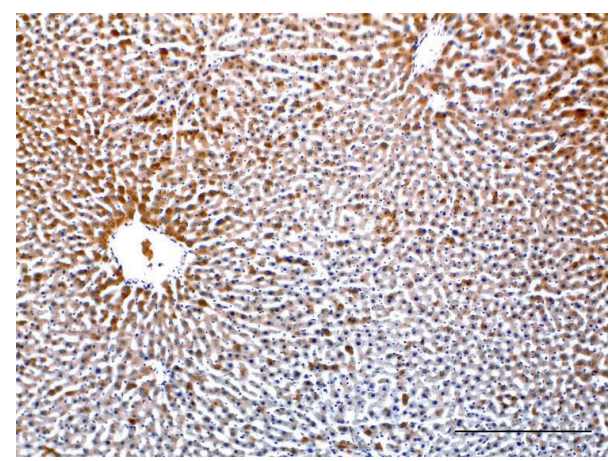

(b)

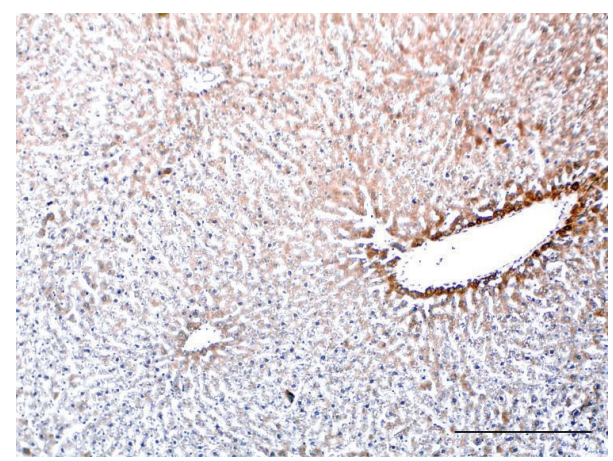

(d)

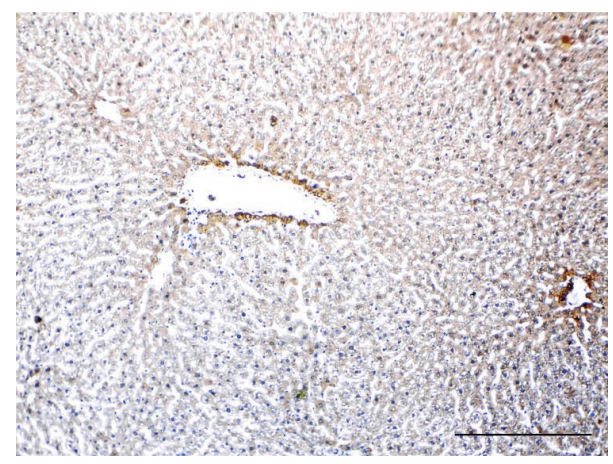

(f)

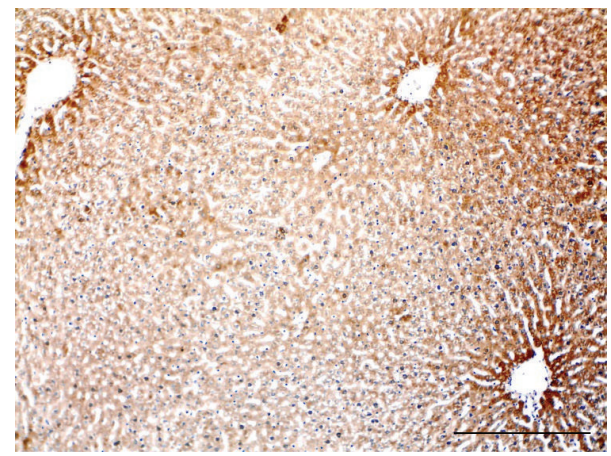

(h)

FIGURE 2: Immunohistochemistry localisation of activin type IIA (left column) and IIB (right column) receptors in control (a and b), Peg-only (c and d), Peg \& RBV (e and f), and RBV-only ( $g$ and h) groups ( $\times 100$ magnification, scale bar $=15 \mu \mathrm{m})$. 


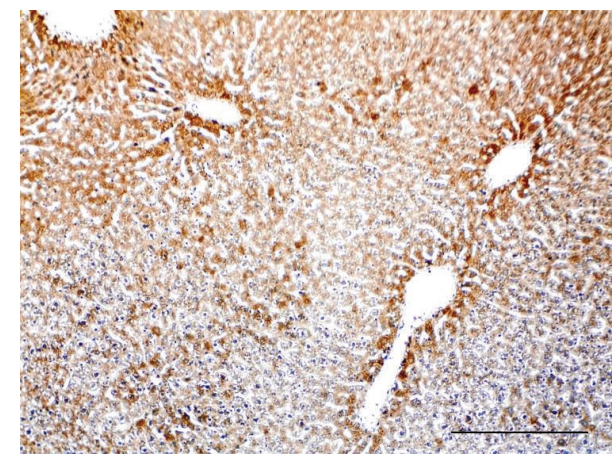

(a)

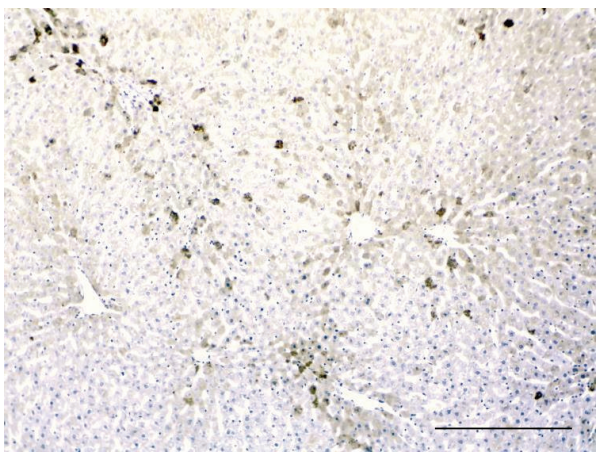

(c)

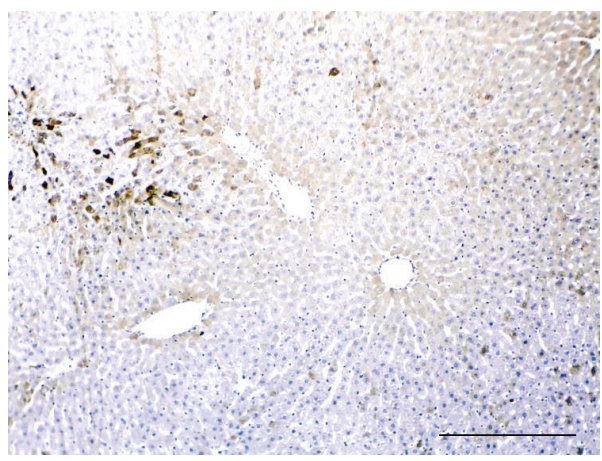

(e)

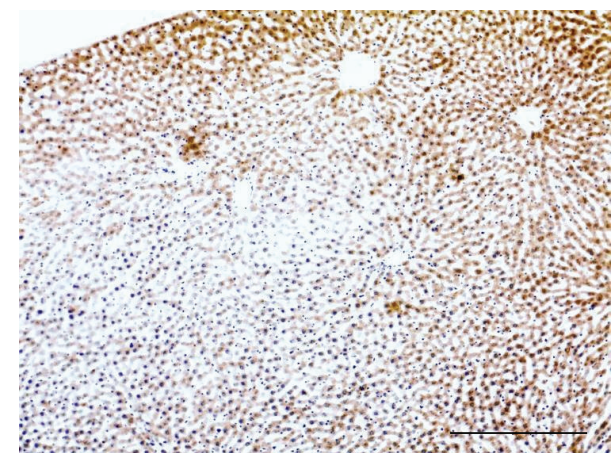

(g)

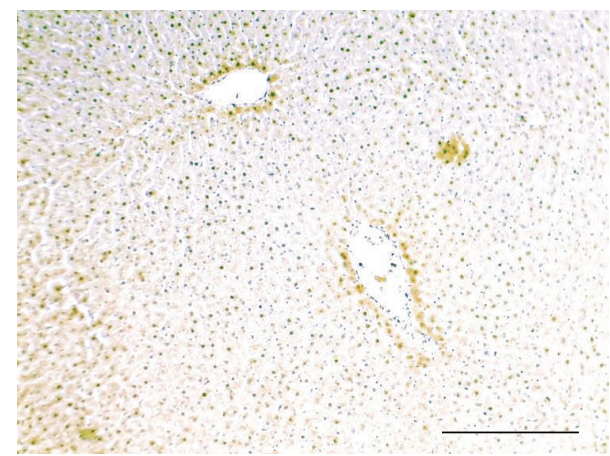

(b)

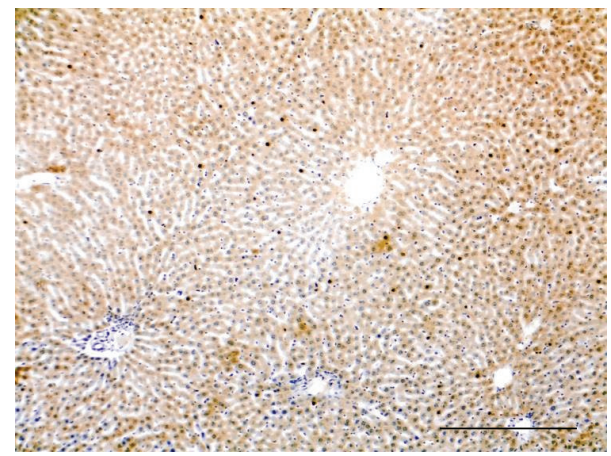

(d)

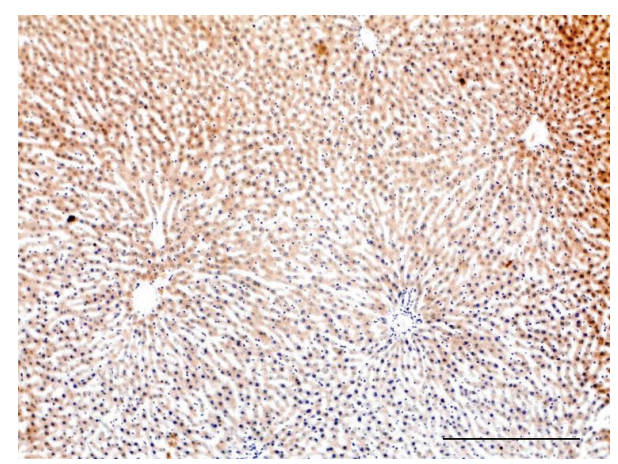

(f)

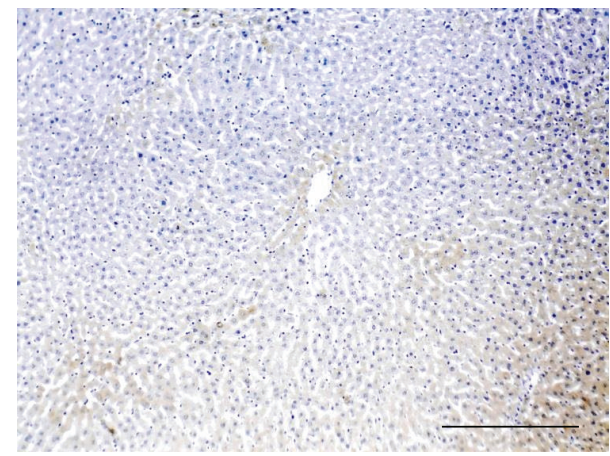

(h)

Figure 3: Immunohistochemistry localisation of Smad4 (left column) and Smad7 (right column) in control (a and b), Peg-only (c and d), Peg \& RBV (e and f), and RBV-only (g and h) groups ( $\times 100$ magnification, scale bar $=15 \mu \mathrm{m})$. 


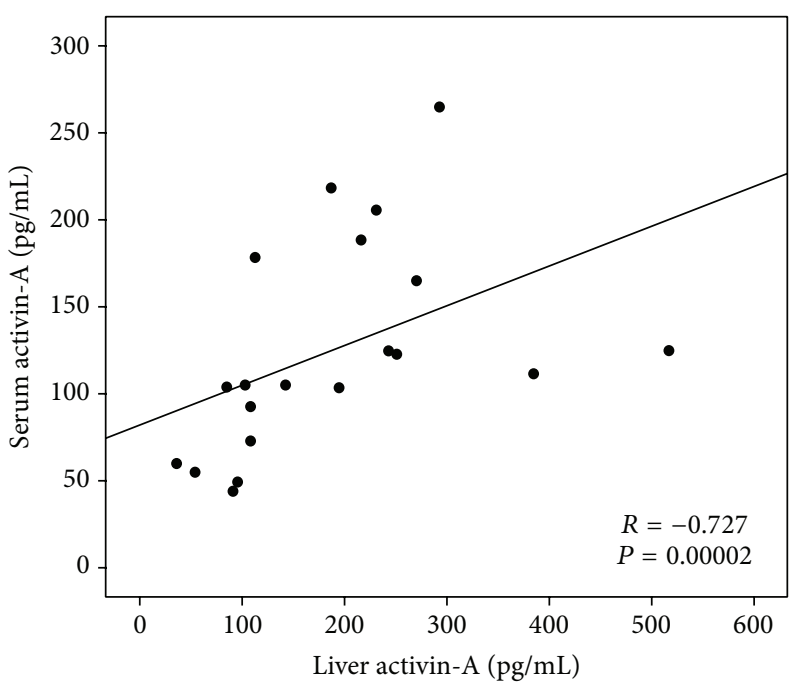

(a)

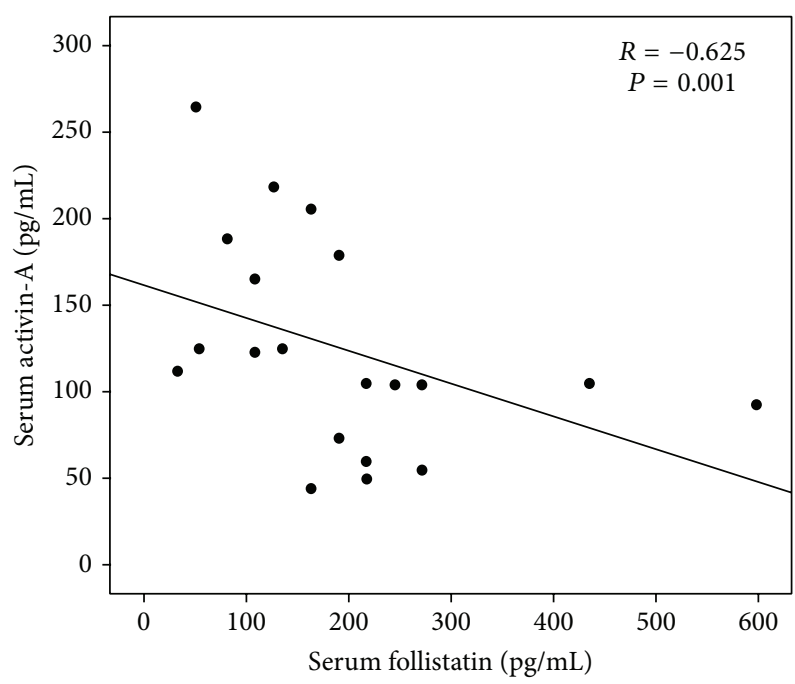

(c)

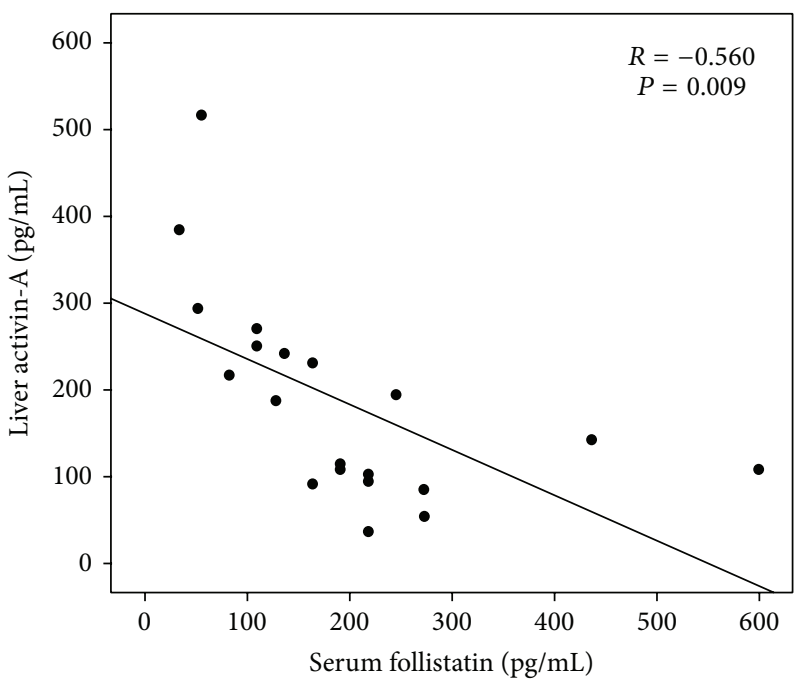

(e)

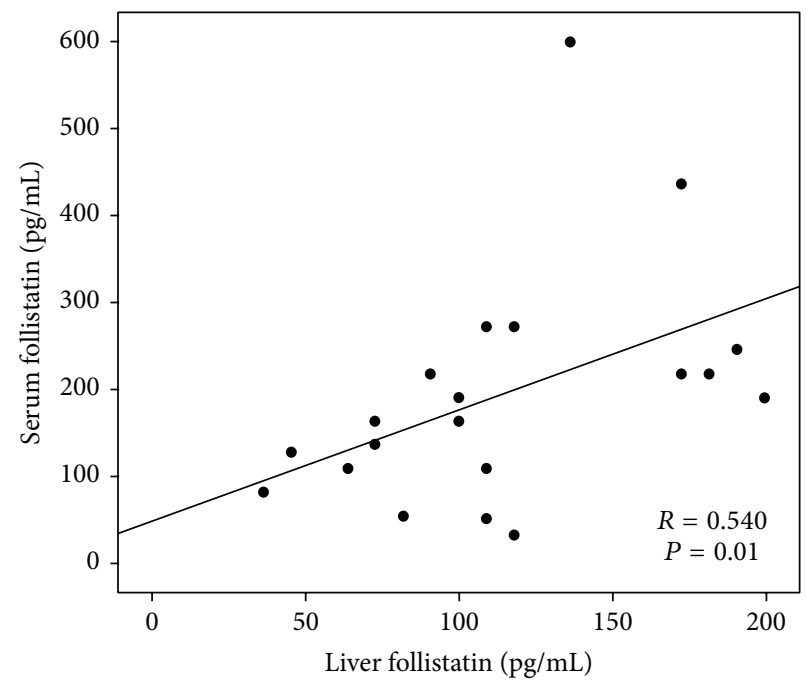

(b)

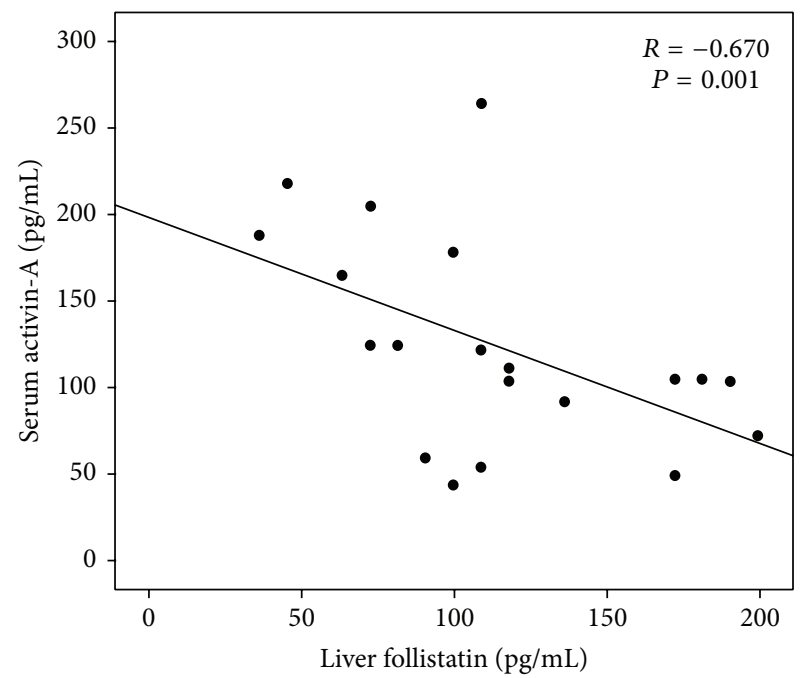

(d)

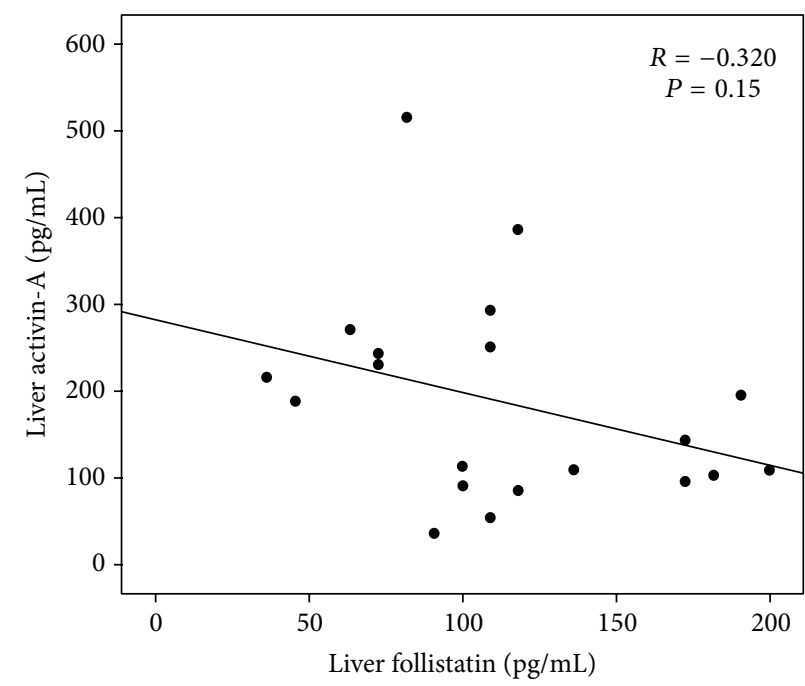

(f)

FIgURE 4: Correlation between (a) serum and liver activin-A, (b) serum and liver follistatin, (c) serum activin-A and serum follistatin, (d) serum activin-A and liver follistatin, (e) liver activin-A and serum follistatin, and (f) liver activin-A and follistatin by Pearson's correlation test. 


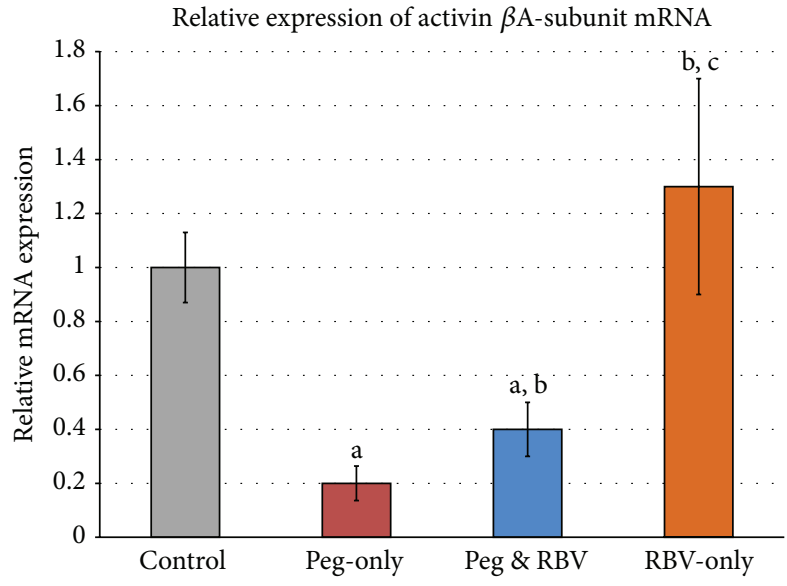

(a)

Relative expression of activin type IIA receptor mRNA

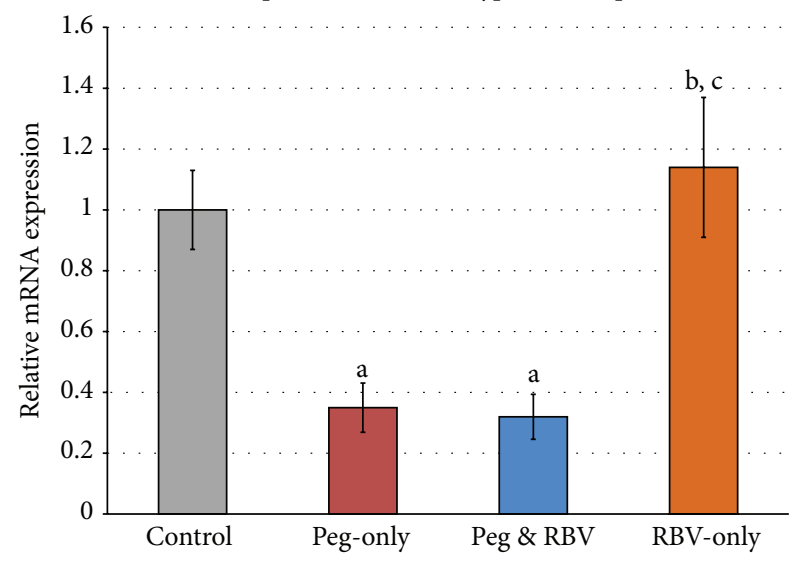

(c)

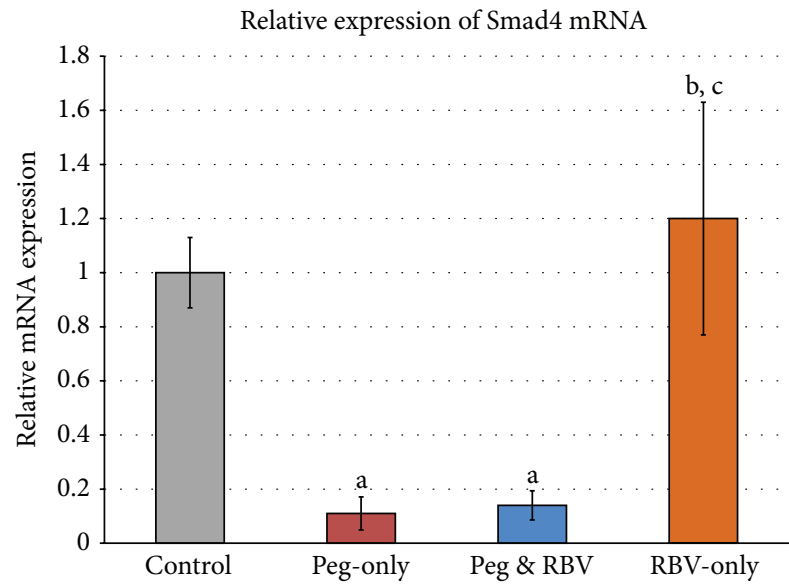

(e)

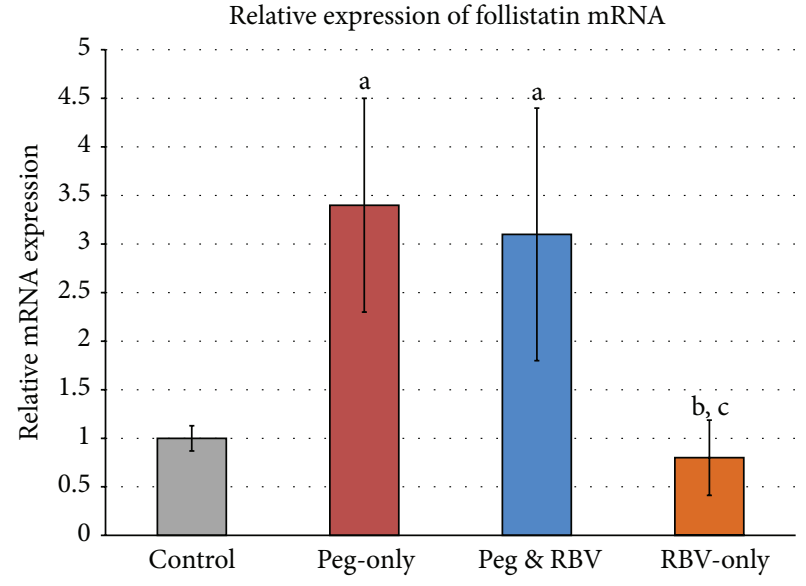

(b)

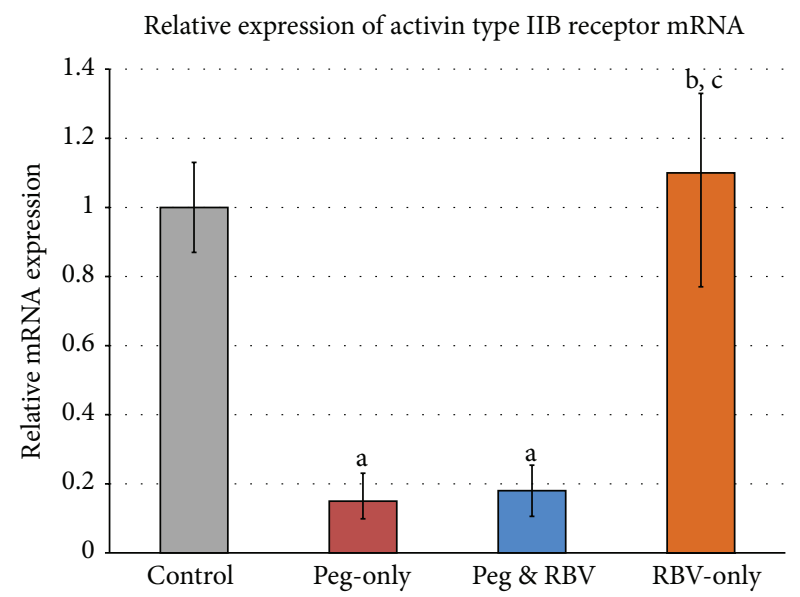

(d)

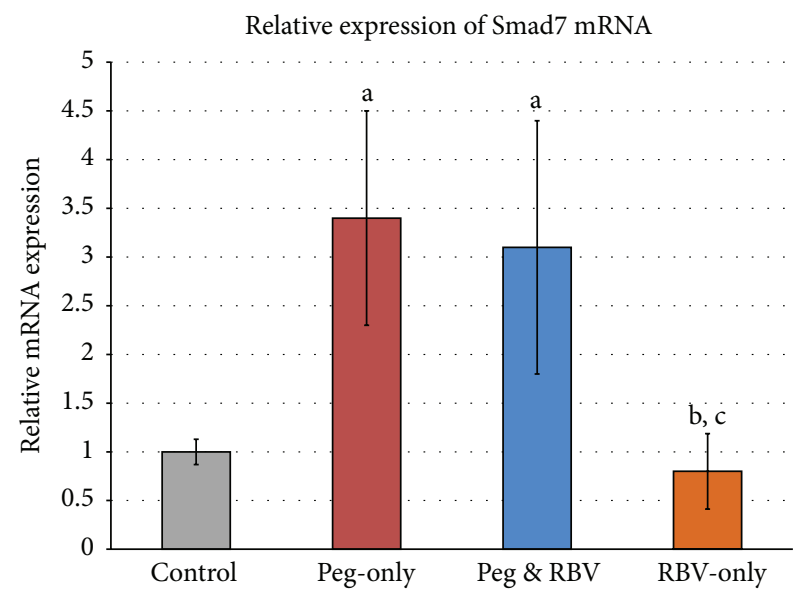

(f)

FIGURE 5: Relative concentration of messenger RNA expression of (a) activin $\beta$ A-subunit, (b) follistatin, (c) type IIA receptor, (d) type IIB receptor, (e) Smad4, and (f) Smad7 in the different study groups $\left({ }^{\mathrm{a}} P<0.05\right.$ compared to control, ${ }^{\mathrm{b}} P<0.05$ compared to Peg-only, and ${ }^{c} P<0.05$ compared to Peg \& RBV group). 
TABLE 2: Mean \pm SD of body weight, total liver weight, liver enzymes, albumin, renal function, and metabolic parameters in the different study groups.

\begin{tabular}{lcccc}
\hline & Control & Peg-INF only & Peg-INF \& ribavirin & Ribavirin only \\
\hline Body weight (g) & $221.57 \pm 20.01$ & $231.97 \pm 23.01$ & $218.42 \pm 13.64$ & $230.1 \pm 22.2$ \\
Liver weight (g) & $11.04 \pm 1.26$ & $10.54 \pm 1.52$ & $10.27 \pm 0.44$ & $10.23 \pm 1.5$ \\
ALT (U/L) & $60.4 \pm 16.2$ & $68.8 \pm 18.6$ & $53.9 \pm 19$ & $64.1 \pm 11.5$ \\
AST (U/L) & $92.4 \pm 24.2$ & $129.8 \pm 46.7$ & $119 \pm 21.6$ & $133 \pm 49.8$ \\
Albumin (g/dL) & $3.4 \pm 0.4$ & $3.3 \pm 0.5$ & $3.7 \pm 0.3$ & $3.5 \pm 0.5$ \\
Creatinine (mg/dL) & $0.22 \pm 0.03$ & $0.2 \pm 0.06$ & $0.2 \pm 0.03$ & $0.19 \pm 0.03$ \\
Urea (mg/dL) & $47.6 \pm 5.1$ & $52.3 \pm 4$ & $56.6 \pm 9.5$ & $47.3 \pm 5.8$ \\
BUN (mg/dL) & $22.2 \pm 2.4$ & $24.4 \pm 1.9$ & $26.3 \pm 4.4$ & $22 \pm 2.7$ \\
Glucose (mg/dL) & $110.7 \pm 12.7$ & $118.9 \pm 23.1$ & $112.6 \pm 12.7$ & $114.5 \pm 16.1$ \\
Triglycerides (mg/dL) & $77.3 \pm 20.3$ & $68.3 \pm 13.9$ & $63.2 \pm 9.5$ & $85 \pm 28.5$ \\
Cholesterol (mg/dL) & $45 \pm 7.2$ & $58.5 \pm 12.4$ & $52.8 \pm 7.8$ & $64.8 \pm 9.7$ \\
HDL-C (g/dL) & $36.2 \pm 9.2$ & $44.3 \pm 1.2$ & $7.1 \pm 2.5$ & $53.1 \pm 7.7$ \\
LDL-C (g/dL) & $6.6 \pm 1.7$ & $8.14 \pm 2.33$ & & $6.3 \pm 1.55$ \\
\hline
\end{tabular}

TABLE 3: Mean \pm SD of immunohistochemistry scores for activin $\beta$ A-subunit, activin type receptor IIA and IIB, Smad4, Smad7, and follistatin proteins in liver specimens.

\begin{tabular}{lcccc}
\hline & Normal group & Peg-only group & Peg \& RBV group & RBV-only group \\
\hline BA-subunit & $215.5 \pm 31.2$ & $96.4 \pm 23.4^{\mathrm{a}}$ & $111.48 \pm 44.3^{\mathrm{a}}$ & $223.9 \pm 38.5^{\mathrm{b}, \mathrm{c}}$ \\
Receptor IIA & $283.7 \pm 58.7$ & $121.4 \pm 29.2^{\mathrm{a}}$ & $135.7 \pm 27.6^{\mathrm{a}}$ & $269.2 \pm 46.8^{\mathrm{a}, \mathrm{b}}$ \\
Receptor IIB & $332.7 \pm 67.6$ & $176.5 \pm 32.6^{\mathrm{a}}$ & $202.4 \pm 41.8^{\mathrm{a}, \mathrm{b}}$ & $294.7 \pm 38.6^{\mathrm{b}, \mathrm{c}}$ \\
Smad4 & $301.1 \pm 26$ & $47.2 \pm 20.3^{\mathrm{a}}$ & $66.1 \pm 23.9^{\mathrm{a}}$ & $258.7 \pm 31.6^{\mathrm{a}, \mathrm{b}, \mathrm{c}}$ \\
Smad7 & $61 \pm 26.7$ & $270.6 \pm 68.7^{\mathrm{a}}$ & $267.6 \pm 55.3^{\mathrm{a}}$ & $89.6 \pm 30.1^{\mathrm{b}, \mathrm{c}}$ \\
Follistatin & $159.4 \pm 9.5$ & $373.1 \pm 66.8^{\mathrm{a}}$ & $351.8 \pm 47.2^{\mathrm{a}}$ & $178.1 \pm 43.6^{\mathrm{b}, \mathrm{c}}$ \\
\hline
\end{tabular}

${ }^{a} P<0.05$ compared with normal; ${ }^{b} P<0.05$ compared with Peg-only group; and ${ }^{c} P<0.05$ compared with Peg \& RBV group.

activin-A, its type II receptors, its intracellular mediators, and follistatin in liver specimens collected from experimental animal model. Our results demonstrated at the gene and protein levels that Peg-INF- $\alpha$ significantly decreased the expression of activin $\beta$ A-subunit, activin type IIA and IIB receptors, and Smad4 in "Peg-only" and "Peg \& RBV" groups compared with "control" and "RBV-only" groups. Simultaneously, the injection of the drug for 4 weeks was also associated with a significant increase in the expression of follistatin and Smad7 mRNAs and proteins by the hepatocyte. Furthermore, similar observations were also noted for the serum concentrations of mature activin-A and follistatin proteins which correlated significantly with the concentrations of activin-A and follistatin in the liver.

Our results suggest that activin-A and its related proteins are potential targets for interferon- $\alpha$ and Peg-INF- $\alpha$, but not ribavirin, modulates the production and actions of these proteins in the liver. Furthermore, the variations in the liver concentrations of activin-A and follistatin mature proteins following Peg-INF- $\alpha$ are reflected and could be detected in serum.

Activins are dimer proteins that consist of two $\beta$-subunits ( $\beta \mathrm{A}$ - and $\beta \mathrm{B}$-subunits) and the different dimerization of subunits gives rise to three proteins: activin-A $(\beta A-\beta A)$, activin$\mathrm{B}(\beta \mathrm{B}-\beta \mathrm{B})$, and activin-AB $(\beta \mathrm{A}-\beta \mathrm{B})$ [3]. Activins initiate their actions by binding to their cell surface type IIA and IIB receptors, leading to the recruitment of type I receptor followed by a cascade of phosphorylation reactions of their intracellular mediators known as Smads to propagate the signal to the nucleus [15]. Activins and their related molecules are expressed in the liver of several species and they are mainly involved in the regulation of hepatocyte regeneration and differentiation $[27,28]$. Several studies have shown that activin-A induces hepatocyte growth arrest and apoptosis in vivo and in vitro and these actions are Smad dependent [29-32]. These effects can be blocked by the activin binding protein, follistatin, which has been demonstrated to promote the growth and differentiation of liver cells [33-35]. Hence, it has been suggested that activins are tightly regulated in the liver and pathological alterations in the activin-follistatin axis have been associated with several hepatic disorders including viral and nonviral diseases [20, 21, 36-39].

Our results correlate with the previous studies as they showed the expression of activin $\beta$ A-subunit, activin type IIA and IIB receptors, its binding protein, and its intracellular mediators Smad4 and Smad7. Our results support the assumption that activins act through paracrine/autocrine mode of action in the liver and their functions are tightly regulated in the liver.

Activins and follistatin are also involved in the regulation of the immune system and pathological expression of these proteins has been reported in a variety of immune and inflammatory responses [40-42]. Furthermore, the production and expression of activins, their intracellular mediators, 
TABLE 4: Mean \pm SD of serum and liver concentrations of activin-A and follistatin in the different groups.

\begin{tabular}{lcccc}
\hline & \multicolumn{2}{c}{ Activin-A $(\mathrm{pg} / \mathrm{mL})$} & \multicolumn{2}{c}{ Follistatin $(\mathrm{pg} / \mathrm{mL})$} \\
Serum & Liver & Serum & $72.6 \pm 22.1$ \\
Control & $166.5 \pm 41.7$ & $216.1 \pm 45.7$ & $128.9 \pm 40.9$ & $157.4 \pm 28.5^{\mathrm{a}}$ \\
Peg-only & $92.08 \pm 15.3^{\mathrm{a}}$ & $115.2 \pm 37.5^{\mathrm{a}}$ & $354.15 \pm 91.1^{\mathrm{a}}$ & \\
Peg \& RBV & $56.5 \pm 10.9^{\mathrm{a}, \mathrm{b}}$ & $112.4 \pm 41.6^{\mathrm{a}}$ & $212.4 \pm 40.4^{\mathrm{a}, \mathrm{b}}$ & \\
RBV-only & $174.7 \pm 35.8^{\mathrm{b}, \mathrm{c}}$ & $281.8 \pm 84.2^{\mathrm{b}, \mathrm{c}}$ & $98.9 \pm 33.4^{\mathrm{b}, \mathrm{c}}$ & \\
\hline
\end{tabular}

${ }^{\mathrm{a}} P<0.05$ compared to control, ${ }^{\mathrm{b}} \mathrm{P}<0.05$ compared to Peg-only, and ${ }^{\mathrm{c}} \mathrm{P}<0.05$ compared to Peg \& RBV group.

and follistatin have been shown to be modulated by interferons in a variety of tissues. Treatment of patients with hepatitis $\mathrm{B}$ virus with IFN- $\gamma$ resulted in a decrease in the fibrosis scores and it has been suggested that the antifibrotic effects of the drug were achieved by upregulating Smad7 expression and impairing the signalling of TGF- $\beta$ through inhibition of Smad4 [43]. Additionally, treating keloid derived fibroblasts with INF- $\gamma$ significantly increased the expression of Smad3 and Smad7 in a time and dose dependent manner [44]. The use of recombinant human interferon- $\beta$ la in vitro on hepatic stellate cells has also shown dose dependent antifibrotic activities by decreasing the expression of Smad 4 and collagen type I and collagen type III with a concurrent increase in the expression of the inhibitory Smad7 [45].

Interferon- $\gamma$ has also been shown to suppress the actions of activin-A by reciprocally regulating the secretion of activin-A and follistatin from bone marrow stromal fibroblasts [46]. A more recent study has also reported that INF$\gamma$ regulates the host immune cells and inhibits alternative macrophage activation during allograft rejection by decreasing the expression of activin $\beta \mathrm{A}$ - and $\beta \mathrm{B}$-subunits [47]. Similar suppressive effects have also been recently reported for INF- $\gamma$ on the activities of activin-A during globin gene expression [48]. We have previously reported that the serum concentrations of activin-A increase dramatically in patients with $\mathrm{CHC}$ and they correlated significantly with the serum levels of IL- 6 , TNF- $\alpha$, and the severity of liver damage associated with $\mathrm{CHC}$ [22]. Later, we have also demonstrated that serum activin-A and follistatin were modulated during the treatment of CHC with Peg-INF- $\alpha$ based therapy and that their levels returned to normal in the responder group [23].

The current findings are in agreement with the previous studies as we observed a significant decrease in the expression of activin $\beta \mathrm{A}$-subunit, activin type II receptors, and Smad 4 in the liver following the use of Peg-INF- $\alpha$ for 4 weeks, which synchronized with a significant increase in the expression of follistatin and inhibitory Smad7. Our results suggest that PegINF- $\alpha$ inhibits the actions of activin-A in the liver by increasing its binding protein and inhibitory Smad7, downregulating activin $\beta \mathrm{A}$-subunit, and inhibiting the production of activin type II receptors and Smad4.

Hence, we hypothesise that activins and their related proteins are potential targets for Peg-INF- $\alpha$ based therapy during the treatment of $\mathrm{CHC}$. In this regard, activin-A has been shown to induce deviation of immune response towards a type 2 phenotype [49], and Peg-INF- $\alpha$ eradicates the viral infection by altering the immune response in patients with CHC from Th2 to a Th1 mediated pattern [8]. Peg-INF- $\alpha$ based therapy also increases the expression of toll-like receptors 2 and 4 in patients with CHC [50], which are potent regulators of the release of activin-A [51, 52]. Additionally, the production of TNF- $\alpha$ in the natural killer cells increases and that of serum IL- 6 and serum IL-10 decreases following PegINF- $\alpha[13,53]$. These cytokines have also been shown to be regulated by activin-A [54]. Moreover, the release of INF- $\gamma$, which plays an important role in controlling $\mathrm{CHC}$ following Peg-INF- $\alpha$ based therapy [55], is regulated by activin-A [47].

Our findings of a significant decrease in dimeric activin$A$ and significant increase in follistatin at the serum and liver levels following the administration of Peg-INF- $\alpha$ compared to "control" and "RBV" groups further support our hypothesis that Peg-INF- $\alpha$ alters the production of these proteins at the liver and serum levels. Additionally, the observed significant positive correlations between liver and serum concentrations of activin-A and follistatin suggest that the liver is a major source of these proteins in serum and that alteration in the hepatic volume of these proteins following injection of Peg-INF- $\alpha$ is reflected and detected at the serum level. Further studies are required to illustrate the mechanism(s) by which Peg-INF- $\alpha$ regulate the production of activin-A and follistatin by the liver.

Although follistatin is regarded as the activin binding protein [56], it appears that the production of follistatin is not only driven by activin during inflammation $[57,58]$. The synthesis and secretion of follistatin are also modulated by other cytokines, including IL- $1 \beta$, TNF- $\alpha$, and IFN- $\gamma[46$, 59]. The physiological and pathological activities of activinA are usually antagonised by follistatin at the cellular and serum levels [56]. Our results agree with these findings as they have shown a significant increase in hepatic and serum concentrations of follistatin following treatment with Peg-INF- $\alpha$, suggesting that the drug controls the activities of activin-A by decreasing its production and increasing its binding protein in liver and serum. Additionally, the observed alterations in the expression of activin type II receptors and activin intracellular mediators suggest that Peg-INF- $\alpha$ could regulate the actions of activins in the liver by inhibiting the propagation of the signal through multipathway mechanisms.

Ribavirin monotherapy is not effective in the treatment of $\mathrm{CHC}$ and a number of studies have suggested that strong antiviral activity is only seen when RBV is combined with either INF- $\alpha$ or Peg-INF- $\alpha$. Therefore, the presence of synergism between Peg-INF- $\alpha$ and RBV has been suggested, which has been shown in vitro [60]. Additionally, it has been suggested that RBV may have immune modulatory 
activities, including the regulation of macrophage and $\mathrm{T}$ helper cells produced cytokines, modulation of the Th1/Th2 subset balance, and the enhancement of the expression of interferon stimulated genes [61].

Our results support the previous findings as they have demonstrated a significant decrease in serum activin-A and significant increase in serum follistatin in "Peg \& RBV" group compared to "Peg-only" and "RBV-only" groups. However, these synergistic alterations were only detected at the serum level, suggesting that combined effect of Peg-INF$\alpha$ with ribavirin modulates the production of the candidate molecules at other organs/systems beside the liver, affecting the concentrations of these proteins at the serum level.

The biological activities of activins are tightly regulated by follistatin as the binding of activin to follistatin is almost irreversible [15]. Serum activin is commonly bound with the long form of follistatin (FS-315) [62], while the short form of (FS-288) has high affinity for cell membrane activins [63]. The currently available ELISA kits for the detection of activin$\mathrm{A}$ and follistatin cannot distinguish between the free and bound forms of both proteins. Furthermore, the follistatin kit measures both the long and short forms. Therefore, the reported results in our study are shown at the level of total activin-A and follistatin and the development of ELISA kits that measure the free form of both proteins would expose precisely the effects of Peg-INF- $\alpha$ on the activity of both proteins.

In conclusion, Peg-INF- $\alpha$ modulates the production of activin-A, its type IIA and IIB receptors, intracellular mediators, and binding protein by the liver, which appears to be a major source of activin-A and follistatin. Alterations in the concentrations of activin-A and follistatin in the liver are reflected and can be detected at the serum level. Further studies are needed to explore the role of Peg-INF- $\alpha$ based therapy on the production of activins and follistatin by the liver and immune cells.

\section{Conflict of Interests}

The authors declare that there is no conflict of interests.

\section{Acknowledgments}

This project was funded by the National Science, Technology and Innovation Plan (MARRIFAH), King Abdul Aziz City for Science and Technology (KACST), the Kingdom of Saudi Arabia, Award number 12-MED2302-10. The authors would also like to thank Ms. Athar khojah, Mr. Shakir Ossman, and Mr. Jawad Ahmed from the Laboratory Medicine Department, Faculty of Applied Medical Sciences, Umm Al-Qura University, for processing the samples.

\section{References}

[1] F. M. Averhoff, N. Glass, and D. Holtzman, "Global burden of hepatitis C: considerations for healthcare providers in the United States," Clinical Infectious Diseases, vol. 55, supplement 1, pp. S10-S15, 2012.
[2] M. D. Sadler and S. S. Lee, "Revolution in hepatitis C antiviral therapy," British Medical Bulletin, vol. 113, pp. 31-44, 2015.

[3] B. Refaat, A. M. Ashshi, A. G. El-Shemi, and E. Azhar, "Activins and follistatin in chronic hepatitis $\mathrm{C}$ and its treatment with pegylated-interferon- $\alpha$ based therapy ," Mediators of Inflammation, vol. 2015, Article ID 287640, 16 pages, 2015.

[4] M. Stepanova and Z. M. Younossi, "Interferon-free regimens for chronic Hepatitis C: barriers due to treatment candidacy and insurance coverage," Digestive Diseases and Sciences, 2015.

[5] M. Hellard and N. Scott, "The changing landscape of hepatitis C treatment-not 'can we cure?' but 'who should we cure first?' Is this an ethical approach?" Addiction, vol. 110, no. 6, pp. 984-985, 2015.

[6] M. Colombo, "Interferon-free therapy for hepatitis C: the hurdles amid a golden era," Digestive and Liver Disease, 2015.

[7] S. Bansal, A. K. Singal, B. M. McGuire, and B. S. Anand, "Impact of all oral anti-hepatitis C virus therapy: a meta-analysis," World Journal of Hepatology, vol. 7, no. 5, pp. 806-813, 2015.

[8] J. D. Farrar and K. M. Murphy, “Type I interferons and T helper development," Immunology Today, vol. 21, no. 10, pp. 484-489, 2000.

[9] M. A. Jimenez-Sousa, R. Almansa, C. de La Fuente et al., "Increased Th1, Th17 and pro-fibrotic responses in hepatitis Cinfected patients are down-regulated after 12 weeks of treatment with pegylated interferon plus ribavirin," European Cytokine Network, vol. 21, no. 2, pp. 84-91, 2010.

[10] M. Moser and K. M. Murphy, "Dendritic cell regulation of TH1TH2 development," Nature Immunology, vol. 1, no. 3, pp. 199205, 2000.

[11] P. Fallahi, C. Ferri, S. M. Ferrari, A. Corrado, D. Sansonno, and A. Antonelli, "Cytokines and HCV-related disorders," Clinical and Developmental Immunology, vol. 2012, Article ID 468107, 10 pages, 2012.

[12] H. Tilg, "New insights into the mechanisms of interferon alfa: an immunoregulatory and anti-inflammatory cytokine," Gastroenterology, vol. 112, no. 3, pp. 1017-1021, 1997.

[13] M. Ueyama, M. Nakagawa, N. Sakamoto et al., "Serum interleukin-6 levels correlate with resistance to treatment of chronic hepatitis $\mathrm{C}$ infection with pegylated-interferon-alpha2b plus ribavirin," Antiviral Therapy, vol. 16, no. 7, pp. 1081-1091, 2011.

[14] E.-J. Pavón-Castillero, P. Muñoz-de-Rueda, R. López-Segura et al., "Importance of IL-10 and IL-6 during chronic hepatitis c genotype-1 treatment and their relation with IL28B," Cytokine, vol. 61, no. 2, pp. 595-601, 2013.

[15] B. A. Refaat, A. O. Bahathiq, S. Sockanathan, R. L. Stewart, M. Wells, and W. L. Ledger, "Production and localization of activins and activin type IIA and IIB receptors by the human endosalpinx," Reproduction, vol. 128, no. 2, pp. 249-255, 2004.

[16] S. Itoh and P. ten Dijke, "Negative regulation of TGF- $\beta$ receptor/Smad signal transduction," Current Opinion in Cell Biology, vol. 19, no. 2, pp. 176-184, 2007.

[17] A. Weiss and L. Attisano, "The TGFbeta superfamily signaling pathway," Wiley Interdisciplinary Reviews: Developmental Biology, vol. 2, no. 1, pp. 47-63, 2013.

[18] C. Rodgarkia-Dara, S. Vejda, N. Erlach et al., "The activin axis in liver biology and disease," Mutation Research, vol. 613, no. 2-3, pp. 123-137, 2006.

[19] S. Werner and C. Alzheimer, "Roles of activin in tissue repair, fibrosis, and inflammatory disease," Cytokine and Growth Factor Reviews, vol. 17, no. 3, pp. 157-171, 2006. 
[20] S. Patella, D. J. Phillips, D. M. de Kretser, L. W. Evans, N. P. Groome, and W. Sievert, "Characterization of serum activin-A and follistatin and their relation to virological and histological determinants in chronic viral hepatitis," Journal of Hepatology, vol. 34, no. 4, pp. 576-583, 2001.

[21] M. Y. Elsammak, G. M. Amin, G. M. Khalil, W. S. Ragab, and M. M. Abaza, "Possible contribution of serum activin A and IGF1 in the development of hepatocellular carcinoma in Egyptian patients suffering from combined hepatitis $\mathrm{C}$ virus infection and hepatic schistosomiasis," Clinical Biochemistry, vol. 39, no. 6, pp. 623-629, 2006.

[22] B. Refaat, A. Ashshi, A. El-Shemi, and A. AlZanbagi, "Effects of chronic hepatitis $C$ genotype 1 and 4 on serum activins and follistatin in treatment naïve patients and their correlations with interleukin-6, tumour necrosis factor- $\alpha$, viral load and liver damage," Clinical and Experimental Medicine, 2014.

[23] B. Refaat, A. G. El-Shemi, A. M. Ashshi, and A. Alzanbagi, "Serum activins and follistatin during the treatment of chronic hepatitis c genotypes 1 and 4 and their correlations with viral load and liver enzymes: a preliminary report," Gastroenterology Research and Practice, vol. 2014, Article ID 628683, 9 pages, 2014.

[24] M. G. Ghany, D. B. Strader, D. L. Thomas, and L. B. Seeff, "Diagnosis, management, and treatment of hepatitis C: an update," Hepatology, vol. 49, no. 4, pp. 1335-1374, 2009.

[25] A. Prakash, E. Tuckerman, S. Laird, B. Ola, T. C. Li, and W. L. Ledger, "A preliminary study comparing the endometrial expression of inhibin, activin and follistatin in women with a history of implantation failure after IVF treatment and a control group," BJOG: An International Journal of Obstetrics and Gynaecology, vol. 115, no. 4, pp. 532-537, 2008.

[26] B. Refaat, T. H. Ashour, and A. G. El-Shemi, "Ribavirin induced anaemia: the effect of vitamin D supplementation on erythropoietin and erythrocyte indices in normal Wistar rat," International Journal of Clinical and Experimental Medicine, vol. 7, pp. 2667-2676, 2014.

[27] Y.-Q. Zhang, M. Kanzaki, H. Mashima, T. Mine, and I. Kojima, "Characterization of the activin receptor in cultured rat hepatocytes," Hepatology, vol. 24, no. 2, pp. 446-450, 1996.

[28] F. Clotman and F. P. Lemaigre, "Control of hepatic differentiation by activin/TGF $\beta$ signaling," Cell Cycle, vol. 5, no. 2, pp. 168-171, 2006.

[29] K. Takamura, K. Tsuchida, H. Miyake, S. Tashiro, and H. Sugino, "Activin and activin receptor expression changes in liver regeneration in rat," Journal of Surgical Research, vol. 126, no. 1, pp. 3-11, 2005.

[30] R. H. Schwall, K. Robbins, P. Jardieu, L. Chang, C. Lai, and T. G. Terrell, "Activin induces cell death in hepatocytes in vivo and in vitro," Hepatology, vol. 18, no. 2, pp. 347-356, 1993.

[31] J. Ho, C. de Guise, C. Kim, S. Lemay, X.-F. Wang, and J.-J. Lebrun, "Activin induces hepatocyte cell growth arrest through induction of the cyclin-dependent kinase inhibitor p15INK4B and Sp1," Cellular Signalling, vol. 16, no. 6, pp. 693-701, 2004.

[32] L. Chen, W. Zhang, H.-F. Liang et al., "Activin A induces growth arrest through a SMAD-dependent pathway in hepatic progenitor cells," Cell Communication and Signaling, vol. 12, no. 1, article 18, 2014.

[33] K. Takamura, K. Tsuchida, H. Miyake, S. Tashiro, and H. Sugino, "Possible endocrine control by follistatin 315 during liver regeneration based on changes in the activin receptor after a partial hepatectomy in rats," Hepato-Gastroenterology, vol. 52, no. 61, pp. 60-66, 2005.
[34] E. J. Gold, X. Zhang, A. M. Wheatley et al., " $\beta$ A- and $\beta C$-activin, follistatin, activin receptor mRNA and $\beta$ C-activin peptide expression during rat liver regeneration," Journal of Molecular Endocrinology, vol. 34, no. 2, pp. 505-515, 2005.

[35] M. Fujii, M. Ishikawa, M. Iuchi, and S. Tashiro, "Effect of follistatin on rat liver regeneration and tumor growth after portal occlusion," Hepato-Gastroenterology, vol. 52, no. 63, pp. 833-838, 2005.

[36] E. J. Gold, R. J. B. Francis, A. Zimmermann et al., "Changes in activin and activin receptor subunit expression in rat liver during the development of $\mathrm{CCl}_{4}$-induced cirrhosis," Molecular and Cellular Endocrinology, vol. 201, no. 1-2, pp. 143-153, 2003.

[37] A. Yndestad, J. W. Haukeland, T. B. Dahl et al., "A complex role of activin A in non-alcoholic fatty liver disease," The American Journal of Gastroenterology, vol. 104, no. 9, pp. 2196-2205, 2009.

[38] R. D. Hughes and L. W. Evans, "Activin A and follistatin in acute liver failure," European Journal of Gastroenterology and Hepatology, vol. 15, no. 2, pp. 127-131, 2003.

[39] A. Yndestad, J. W. Haukeland, T. B. Dahl, B. Halvorsen, and P. Aukrust, "Activin A in nonalcoholic fatty liver disease," Vitamins and Hormones, vol. 85, pp. 323-342, 2011.

[40] A. P. Ofstad, L. Gullestad, E. Orvik et al., "Interleukin-6 and activin A are independently associated with cardiovascular events and mortality in type 2 diabetes: the prospective Asker and Bærum Cardiovascular Diabetes (ABCD) cohort study," Cardiovascular Diabetology, vol. 12, no. 1, article 126, 2013.

[41] O. Yoshino, G. Izumi, J. Shi et al., "Activin-A is induced by interleukin- $1 \beta$ and tumor necrosis factor- $\alpha$ and enhances the mRNA expression of interleukin- 6 and protease-activated receptor-2 and proliferation of stromal cells from endometrioma," Fertility and Sterility, vol. 96, no. 1, pp. 118-121, 2011.

[42] K. Tsumoto, D. Ejima, K. Nagase, and T. Arakawa, "Arginine improves protein elution in hydrophobic interaction chromatography. The cases of human interleukin-6 and activin-A," Journal of Chromatography A, vol. 1154, no. 1-2, pp. 81-86, 2007.

[43] H. Weng, P. R. Mertens, A. M. Gressner, and S. Dooley, "IFN- $\gamma$ abrogates profibrogenic TGF- $\beta$ signaling in liver by targeting expression of inhibitory and receptor Smads," Journal of Hepatology, vol. 46, no. 2, pp. 295-303, 2007.

[44] J. Q. Liu, D. H. Hu, Z. F. Zhang et al., "Effects of interferongamma on the transforming growth factor beta/Smad pathway in keloid-derived fibroblasts," Zhonghua Shao Shang Za Zhi, vol. 25, pp. 454-459, 2009.

[45] H.-Y. Rao, L. Wei, J.-H. Wang et al., "Inhibitory effect of human interferon-beta-la on activated rat and human hepatic stellate cells," Journal of Gastroenterology and Hepatology, vol. 25, no. 11, pp. 1777-1784, 2010.

[46] M. Abe, Y. Shintani, Y. Eto et al., "Interleukin-1 $\beta$ enhances and interferon- $\gamma$ suppresses activin A actions by reciprocally regulating activin $\mathrm{A}$ and follistatin secretion from bone marrow stromal fibroblasts," Clinical and Experimental Immunology, vol. 126, no. 1, pp. 64-68, 2001.

[47] K. S. Famulski, B. Sis, L. Billesberger, and P. F. Halloran, "Interferon-gamma and donor MHC class I control alternative macrophage activation and activin expression in rejecting kidney allografts: a shift in the Th1-Th2 paradigm," The American Journal of Transplantation, vol. 8, no. 3, pp. 547-556, 2008.

[48] W.-H. Lee, M.-H. Chung, Y.-H. Tsai, J.-L. Chang, and H.-M. Huang, "Interferon- $\gamma$ suppresses activin A/NF-E2 induction of erythroid gene expression through the NF- $\kappa \mathrm{B} / \mathrm{c}$-Jun pathway," American Journal of Physiology_Cell Physiology, vol. 306, no. 4, pp. C407-C414, 2014. 
[49] E. Sierra-Filardi, A. Puig-Kröger, F. J. Blanco et al., "Activin A skews macrophage polarization by promoting a proinflammatory phenotype and inhibiting the acquisition of antiinflammatory macrophage markers," Blood, vol. 117, no. 19, pp. 5092-5101, 2011.

[50] T. Hammond, S. Lee, M. W. Watson et al., "Toll-like receptor (TLR) expression on $\mathrm{CD}^{+}$and $\mathrm{CD} 8^{+} \mathrm{T}$-cells in patients chronically infected with hepatitis C virus," Cellular Immunology, vol. 264, no. 2, pp. 150-155, 2010.

[51] K. L. Jones, D. M. D. Kretser, S. Patella, and D. J. Phillips, "Activin A and follistatin in systemic inflammation," Molecular and Cellular Endocrinology, vol. 225, no. 1-2, pp. 119-125, 2004.

[52] K. L. Jones, D. M. de Kretser, I. J. Clarke, J.-P. Y. Scheerlinck, and D. J. Phillips, "Characterisation of the rapid release of activin A following acute lipopolysaccharide challenge in the ewe," Journal of Endocrinology, vol. 182, no. 1, pp. 69-80, 2004.

[53] G. Ahlenstiel, B. Edlich, L. J. Hogdal et al., "Early changes in natural killer cell function indicate virologic response to interferon therapy for hepatitis C," Gastroenterology, vol. 141, no. 4, pp. 1231-1239.e2, 2011.

[54] M. Semitekolou, T. Alissafi, M. Aggelakopoulou et al., "ActivinA induces regulatory $\mathrm{T}$ cells that suppress $\mathrm{T}$ helper cell immune responses and protect from allergic airway disease," Journal of Experimental Medicine, vol. 206, no. 8, pp. 1769-1785, 2009.

[55] T. N. Q. Pham, D. M. H. Lin, P. M. Mulrooney-Cousins et al., "Hepatitis $\mathrm{C}$ virus load and expression of a unique subset of cellular genes in circulating lymphoid cells differentiate nonresponders from responders to pegylated interferon alpharibavirin treatment," Journal of Medical Virology, vol. 85, no. 3, pp. 441-448, 2013.

[56] B. Refaat, S. Amer, B. Ola, N. Chapman, and W. Ledger, "The expression of activin-betaA- and -betaB-subunits, follistatin, and activin type II receptors in fallopian tubes bearing an ectopic pregnancy," Journal of Clinical Endocrinology and Metabolism, vol. 93, no. 1, pp. 293-299, 2008.

[57] A. L. Blount, J. M. Vaughan, W. W. Vale, and L. M. Bilezikjian, "A smad-binding element in intron 1 participates in activindependent regulation of the follistatin gene," The Journal of Biological Chemistry, vol. 283, no. 11, pp. 7016-7026, 2008.

[58] K. M. Wilson, A. I. Smith, and D. J. Phillips, "Stimulatory effects of lipopolysaccharide on endothelial cell activin and follistatin," Molecular and Cellular Endocrinology, vol. 253, no. 1-2, pp. 30$35,2006$.

[59] J. A. Keelan, R. L. Zhou, L. W. Evans, N. P. Groome, and M. D. Mitchell, "Regulation of activin A, inhibin A, and follistatin production in human amnion and choriodecidual explants by inflammatory mediators," Journal of the Society for Gynecologic Investigation, vol. 7, no. 5, pp. 291-296, 2000.

[60] G. Lutchman, S. Danehower, B.-C. Song et al., "Mutation rate of the hepatitis C virus NS5B in patients undergoing treatment with ribavirin monotherapy," Gastroenterology, vol. 132, no. 5, pp. 1757-1766, 2007.

[61] N. J. Stevenson, A. G. Murphy, N. M. Bourke, C. A. Keogh, J. E. Hegarty, and C. O'Farrelly, "Ribavirin enhances IFN- $\alpha$ signalling and MxA expression: a novel immune modulation mechanism during treatment of HCV," PLoS ONE, vol. 6, no. 11, Article ID e27866, 2011.

[62] A. L. Schneyer, H. A. Hall, G. Lambert-messerlian, Q. F. Wang, P. Sluss, and W. F. Crowley Jr., "Follistatin-activin complexes in human serum and follicular fluid differ immunologically and biochemically," Endocrinology, vol. 137, no. 1, pp. 240-247, 1996.
[63] T. Nakamura, K. Sugino, K. Titani, and H. Sugino, "Follistatin, an activin-binding protein, associates with heparan sulfate chains of proteoglycans on follicular granulosa cells," The Journal of Biological Chemistry, vol. 266, no. 29, pp. 19432-19437, 1991. 


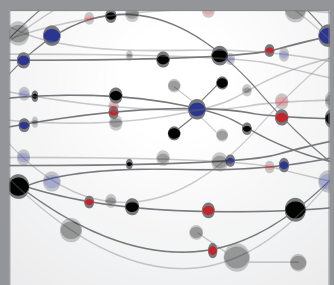

The Scientific World Journal
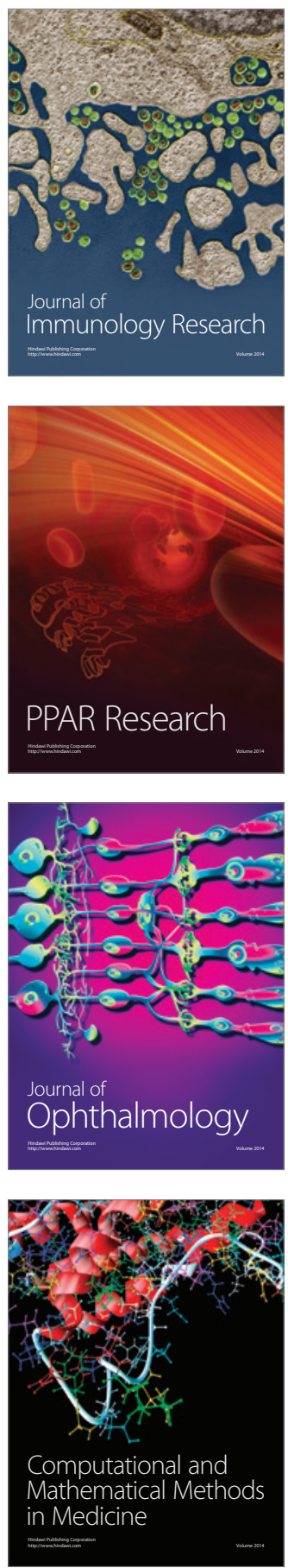

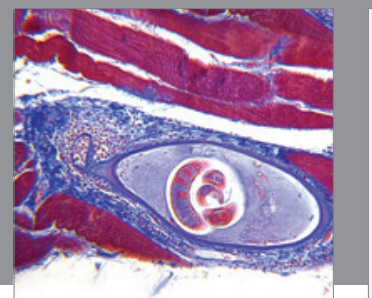

Gastroenterology

Research and Practice
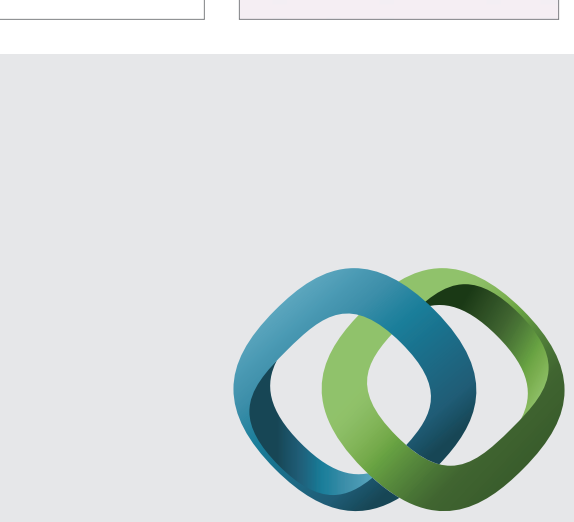

\section{Hindawi}

Submit your manuscripts at

http://www.hindawi.com
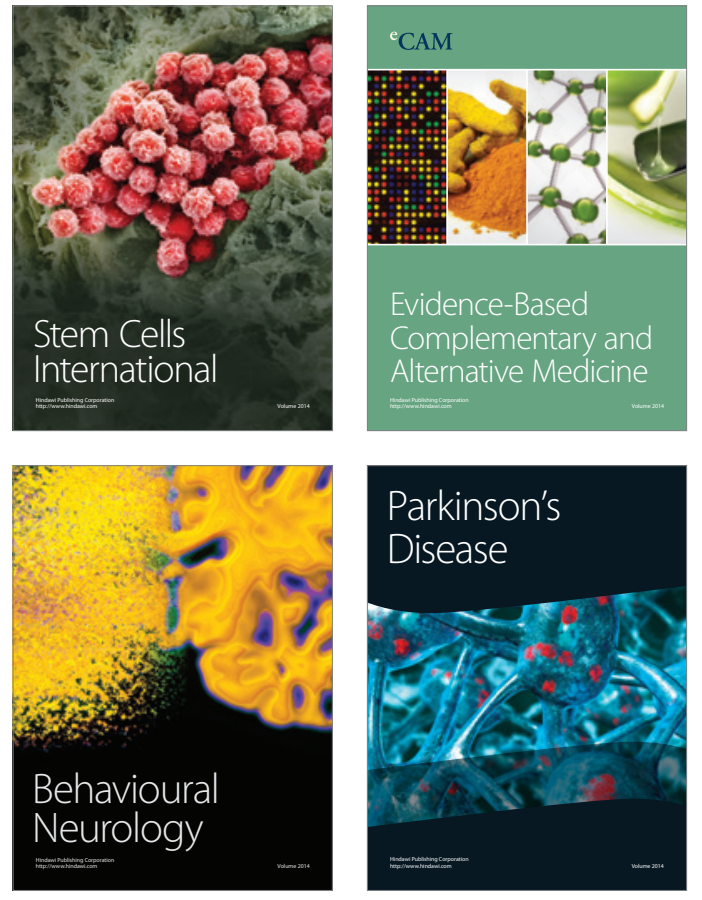
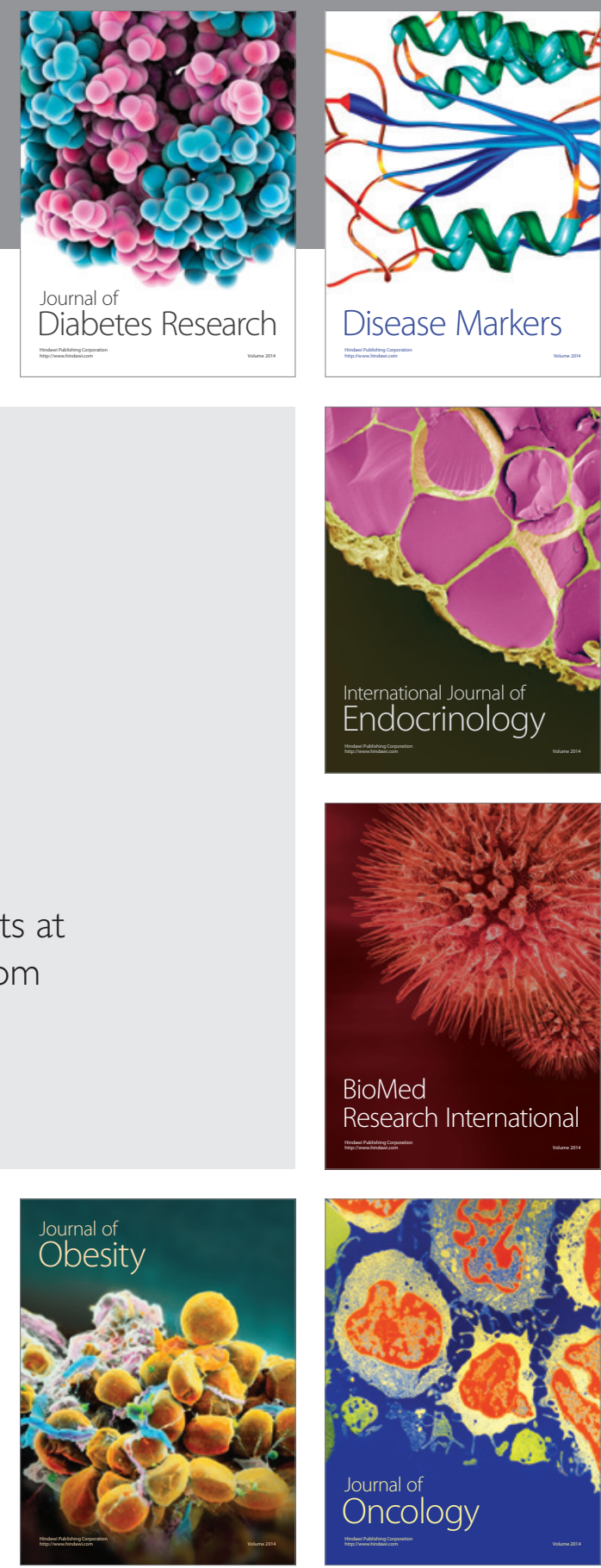

Disease Markers
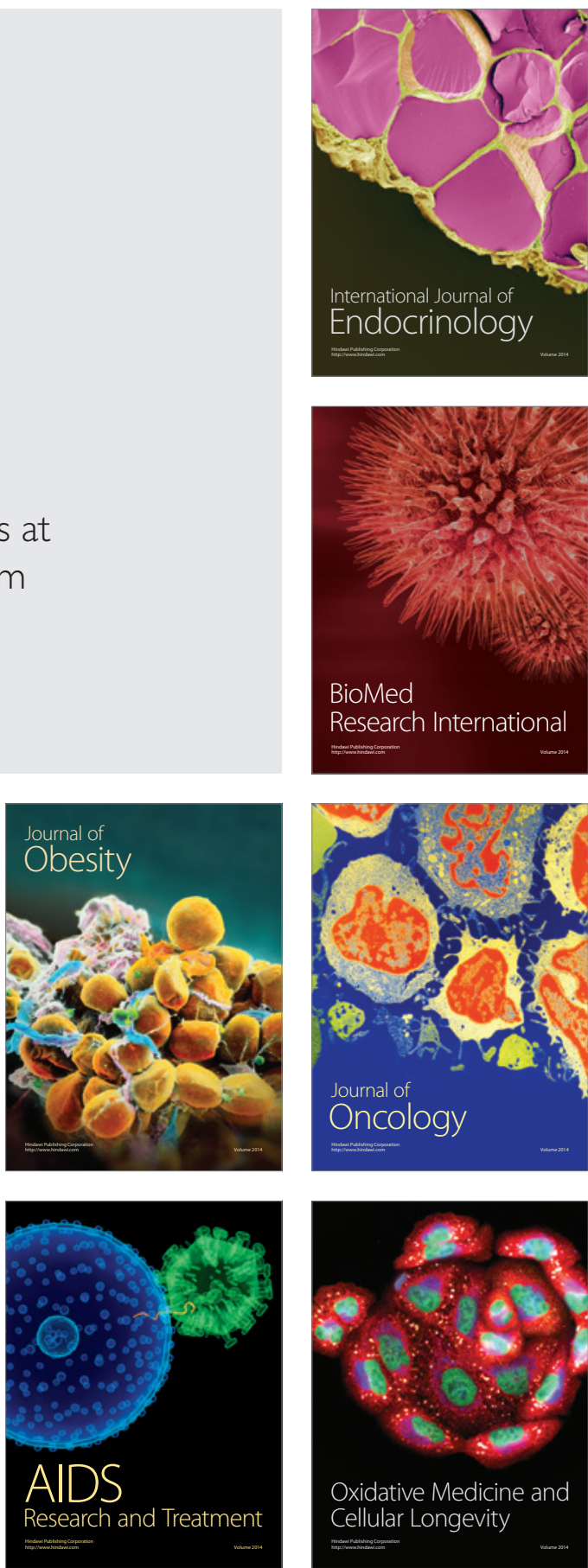